\title{
A Numerical Taxonomic Study of Members of the Actinomycetaceae and Related Taxa
}

\author{
By GERALDINE M. SCHOFIELD AND KLAUS P. SCHAAL* \\ Hygiene Institut of the University of Cologne, Goldenfelsstrasse 21, $5000 \mathrm{Köln} \mathrm{41,}$ \\ Federal Republic of Germany
}

(Received 22 December 1980; revised 30 March 1981)

\begin{abstract}
Two hundred and twenty-two representatives of the Actinomycetaceae and related taxa, including reference cultures, received strains and fresh isolates, were tested using 124 unit characters. The data were examined using numerical taxonomic techniques with various coefficients and average linkage clustering; the variation in composition of the clusters obtained from the different coefficients was slight. Most species included in the study formed discrete phena, which exhibited good differential characters. Actinomyces israelii was particularly well-defined and $A$. naeslundii and $A$. viscosus, although grouping together, did show divergence in several test results. Actinomyces bovis was initially linked with representatives of genera other than Actinomyces, these being Bifidobacterium, Corynebacterium pyogenes and Erysipelothrix rhusiopathiae. The strains of Bacterionema matruchotii and Rothia dentocariosa formed tight distinct clusters associated only at low similarity levels with other members of the family Actinomycetaceae. The Arachnia propionica phenon, although well-defined, appeared to consist of two subclusters which could be assigned to serotypes 1 and 2 . Tests which may be useful in identification are tabulated and the relationships between the various taxa are discussed.
\end{abstract}

\section{INTRODUCTION}

Gram-positive, non-spore-forming bacteria which are predominantly diphtheroid in shape but tend to form branched filaments, and possess a fermentative carbohydrate metabolism, fulfil the basic requirements for being placed in the family Actinomycetaceae as defined in the 8th edition of Bergey's Manual of Determinative Bacteriology (Slack, 1974). However, although usually highly distinctive of Actinomycetaceae, similar properties may well be found in members of other families, e.g. Propionibacteriaceae (Moore \& Holdeman, 1974; Schaal et al., 1980). Therefore, classification and especially identification of fermentative actinomycetes still present problems despite the contributions of modern taxonomic techniques. Methods such as cell wall, lipid and acid end-product analyses are useful for defining fermentative actinomycetes at the genus level (Schaal et al., 1980; Schaal \& Schofield, 1981 a, b; Slack \& Gerencser, 1975). However, the definition of most of the actinomycete species, especially in the genus Actinomyces, is still unsatisfactory.

Morphological resemblances played an important role in previous classification systems. However, cellular and colonial morphology may vary considerably within, as well as between, different species, and thus may not draw clear lines of demarcation between organisms of different taxonomic affiliation (Schaal et al., 1980; Schaal \& Pulverer, 1981). Physiological and biochemical tests which are frequently used in identification of fermentative actinomycete species are difficult to standardize (see Slack \& Gerencser, 1975).

As yet, genetic data (Coykendall \& Munzenmaier, 1979; Johnson \& Cummins, 1972) have contributed little towards the clarification of this area of bacterial taxonomy. The techniques 
for the determination of GC ratios and DNA : DNA reassociation are relatively complex and time-consuming and, therefore, are usually performed on only a few strains. If these strains have been previously incorrectly classified, interpretation of the results is difficult.

Only a few numerical taxonomic studies of Actinomycetaceae have been reported (Holmberg \& Hallander, 1973; Holmberg \& Nord, 1975; Melville, 1965). In these surveys there was considerable reliance on colonial and cell morphology and many of the physiological tests included were those initially designed for aerobic bacteria. A recent limited numerical study of 48 strains (Fillery et al., 1978) included serological and cell wall information and little morphological data. This separated strains of Actinomyces naeslundii and Actinomyces viscosus into distinct groups, but produced few physiological characters useful for identification.

We have therefore undertaken a numerical taxonomic study of the Actinomycetaceae and related taxa in order to improve the classification of these organisms and also to provide rapid and reliable tests for identification.

\section{METHODS}

Strains and cultivation. The bacteria investigated were 107 reference cultures and received strains (Table 1), together with 115 fresh isolates. The latter mostly originated from pus or sinus discharge, and had been tentatively identified using fermentation tests (Minitek system; Becton Dickinson and Co., Heidelberg, F.R.G.) and indirect immunofluorescence (Schaal \& Pulverer, 1973). The strains were lyophilized and working stocks were maintained in Fortner plates (Fortner, 1928, 1929) on CC medium (Heinrich \& Korth, 1967). Before testing, the strains were grown for $7 \mathrm{~d}$ on brain heart infusion agar (BHIA; Oxoid, CM225), either aerobically or anaerobically in GasPak jars (Becton Dickinson), and checked microscopically for purity at $\times 100$ magnification (Schaal \& Pulverer, 1981); at the same time their Gram reaction was determined by Hucker's modification (Cowan \& Steel, 1975). Incubation for all tests was done in the appropriate gaseous atmosphere and, unless otherwise stated, at $37^{\circ} \mathrm{C}$.

Gaseous growth conditions. All strains were tested for their oxygen and/or carbon dioxide requirements using the method described by Slack \& Gerencser (1975).

Catalase. Bacteria from $7 \mathrm{~d}$ cultures on BHIA were tested with $3 \%(\mathrm{v} / \mathrm{v}) \mathrm{H}_{2} \mathrm{O}_{2}$. Anaerobically grown strains were left exposed to air for $1 \mathrm{~h}$ prior to testing.

Cytochrome oxidase. The method of Deibel \& Evans (1960) was used on cultures grown for $7 \mathrm{~d}$ on BHIA.

Deoxyribonuclease. Plates of DNAase medium (Oxoid, CM321) were inoculated, incubated for $7 \mathrm{~d}$ and then examined for a transparent zone around the bacterial growth after flooding with $1 \mathrm{M}-\mathrm{HCl}$.

Hyaluronidase and chondroitin sulphatase. The basal medium was BHI broth (BHIB) plus $10 \mathrm{~g}$ agar $1^{-1}$ (Difco Noble). To this molten cooled base, hyaluronic acid or chondroitin $\left(400 \mu \mathrm{g} \mathrm{m}^{-1}\right)$ was added from a filter sterilized solution. Bovine serum albumin $(1 \%, w / v)$ was added with constant stirring and then $10 \mathrm{ml}$ of each medium was poured on to a $10 \mathrm{ml}$ tap water agar base. After $14 \mathrm{~d}$ incubation, the plates were flooded with $2 \mathrm{M}$-acetic acid, left for $15 \mathrm{~min}$ and then examined for clear zones around the bacterial growth.

Casein, gelatin, starch and Tween hydrolysis, and egg yolk reaction. Various basal media for the different tests were investigated (Slack \& Gerencser, 1975; Cowan \& Steel, 1975; Holdeman \& Moore, 1972) as well as a single base such as BHIA or nutrient agar. However, problems of reproducibility of the results with complex media, or non-growth of some cultures on simpler media were encountered. The basal medium (BM) found to be most suitable was double strength Antibiotics 3 broth (Oxoid, CM287) with $15 \mathrm{~g}$ agar $1^{-1}$ (Oxoid, no. 4). For casein plates, $200 \mathrm{ml}$ of $10 \%(\mathrm{w} / \mathrm{v})$ skim milk (Oxoid, L37) was added to $800 \mathrm{ml}$ of BM at pH 7.2; these plates were examined for clearing at 7 and $14 \mathrm{~d}$ after inoculation. Starch was added to BM at a concentration of $0.5 \%(w / v)$; after $14 \mathrm{~d}$ incubation the medium was flooded with Lugol's iodine solution and examined for a colourless zone around the bacterial growth. Gelatin was added to BM to give a final concentration of $0.4 \%(w / v)$ at pH $7.4 ; 14 \mathrm{~d}$ after inoculation the plates were flooded with Frazier's reagent (Cowan \& Steel, 1975) and examined for clear areas indicating a breakdown of gelatin. Tweens $20,40,60$ or $80\left(1 \%\right.$, v/v; Merck) together with $\mathrm{CaCl}_{2} \cdot 2 \mathrm{H}_{2} \mathrm{O}$ $\left(0.1 \mathrm{~g}^{-1}\right.$, from a $10 \%, \mathrm{w} / \mathrm{v}$, filter-sterilized solution) were added to $\mathrm{BM}$ at $\mathrm{pH} 7.2$; crystal formation in the Tween media was recorded at 7,14 and $21 \mathrm{~d}$. Sterile egg yolk emulsion (Oxoid, SR47), previously heated to $50^{\circ} \mathrm{C}$, was added to cool sterile BM to give a final concentration of $5 \%(v / v)$; plates were examined after 7 and $14 \mathrm{~d}$ incubation for precipitation and for any lipolytic activity.

Tyrosine, guanine, hypoxanthine, xanthine and adenine hydrolysis. Nutrient broth (Difco, 0003-01) at $\mathrm{pH} 7.2$ with $20 \mathrm{~g} \mathrm{agar} \mathbf{1}^{-1}$ (Oxoid, no. 4) was used as the basal medium. Each of the substances was added to give a final concentration of $0.5 \%(\mathrm{w} / \mathrm{v}) ; 10 \mathrm{ml}$ of each test medium was poured on to a tap water agar base, taking care to 
Table 1. Strains and reference cultures, listed in the order in which they occur in Fig. 1

\begin{tabular}{|c|c|c|c|}
\hline Cluster & $\begin{array}{l}\text { Sub- } \\
\text { cluster }\end{array}$ & Strain name/number* & Origin \\
\hline \multirow[t]{5}{*}{1} & $\mathbf{a}$ & $\begin{array}{l}\text { Actinomyces israelii ATCC } 10048 \text { (1) } \\
322 \text { HIK A } 492 / 78 \text { (1) } \\
68 \text { HIK A } 667 / 75\end{array}$ & $\begin{array}{l}\text { Human pleural fluid } \\
\text { Pus, extraoral incision } \\
\text { Tissue from intraoral incision }\end{array}$ \\
\hline & b & 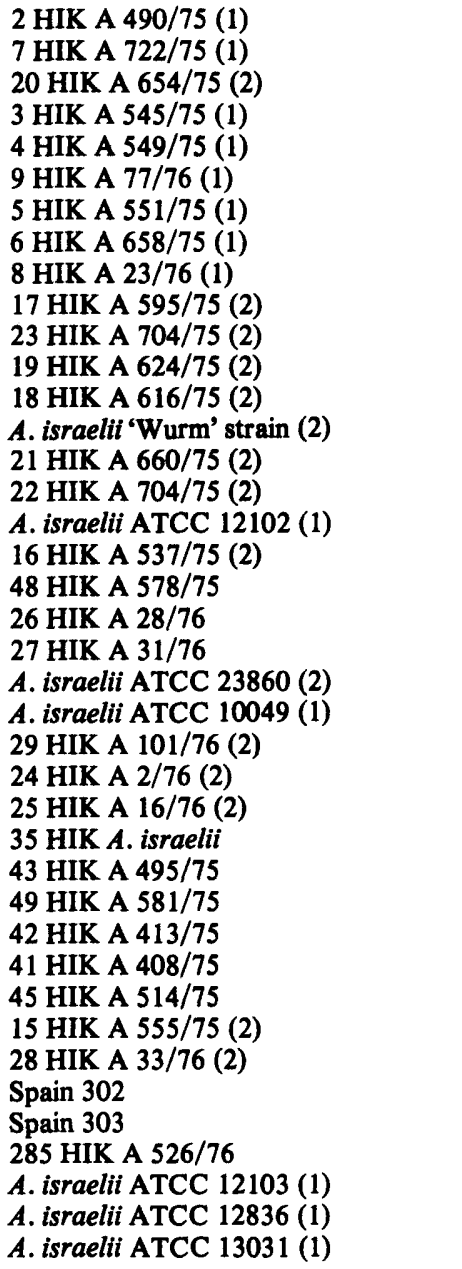 & 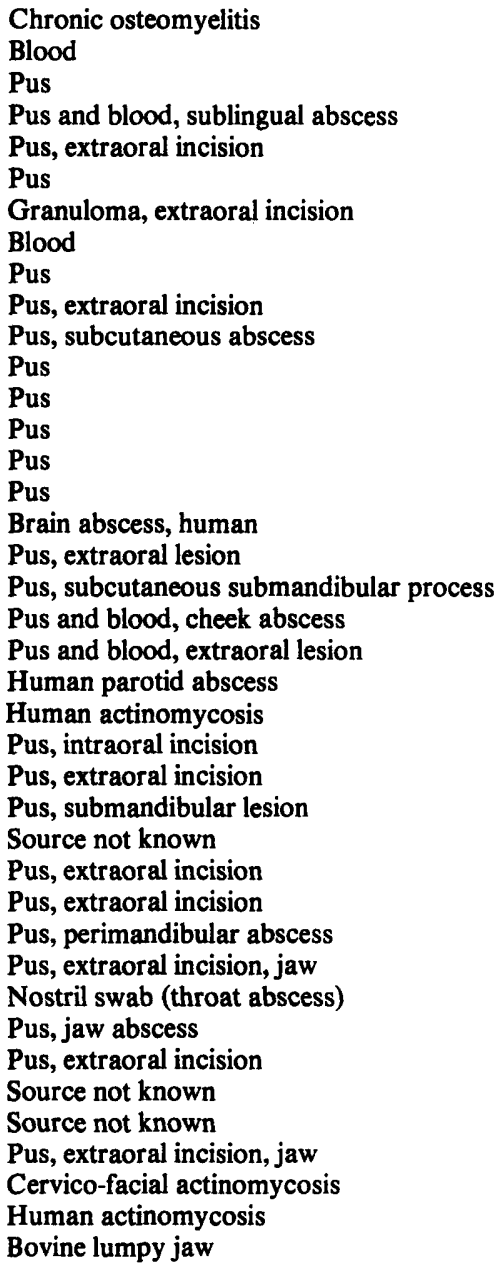 \\
\hline & c & $\begin{array}{l}266 \text { HIK A } 32 / 76 \\
289 \text { HIK A } 666 / 76 \\
294 \text { HIK A } 98 / 77 \\
295 \text { HIK A } 111 / 77 \\
\text { 301 HIK A } 271 / 77\end{array}$ & $\begin{array}{l}\text { Blood and pus, submandibular abscess } \\
\text { Subcutaneous abscess } \\
\text { Granulomatous tissue } \\
\text { Extraoral incision } \\
\text { Pus, jaw abscess }\end{array}$ \\
\hline & $d$ & $\begin{array}{l}39 \text { HIK A } 341 / 75 \\
40 \text { HIK A } 393 / 75 \\
47 \text { HIK A } 563 / 75 \\
50 \text { HIK A } 589 / 75 \\
52 \text { HIK A } 662 / 75 \\
53 \text { HIK A } 4 / 76 \\
51 \text { HIK A } 634 / 75 \\
55 \text { HIK A } 125 / 76 \\
46 \text { HIK A } 527 / 75\end{array}$ & $\begin{array}{l}\text { Pus, chronic jaw process } \\
\text { Pus, subcutaneous submandibùlar abscess } \\
\text { Pus, chronic periodontitis } \\
\text { Oral swab } \\
\text { Pus, extraoral incision } \\
\text { Pus, subcutaneous chin abscess } \\
\text { Pus } \\
\text { Pus } \\
\text { Parotid abscess }\end{array}$ \\
\hline & & $\begin{array}{l}38 \text { HIK A } 302 / 75 \\
88 \text { HIK A } 37 / 76\end{array}$ & $\begin{array}{l}\text { Pus } \\
\text { Pus, extraoral incision }\end{array}$ \\
\hline
\end{tabular}


Table 1 (continued)

Sub-
Cluster
cluster

Not clustered

Not clustered a

\author{
56 HIK A 493/77 \\ A. naeslundii ATCC 12104 (1) \\ 58 HIK $A$. naeslundii \\ 59 HIK A. naeslundii \\ 69 HIK A $177 / 76$ \\ A. naeslundii WVU 398A (1) \\ 65 HIK A $291 / 75$ \\ 76 HIK 8631/68 \\ 77 HIK A $288 / 77$ \\ Poland 20 \\ A. naeslundii CDC W752 (2) \\ 72 HIK A 433/76 \\ Poland 12 \\ 332 HIK $A$. naeslundii \\ A. naeslundii WVU 398A (1) \\ 86 HIK A $609 / 75$ \\ 91 HIK A $633 / 76$ \\ b 286 HIK A 603/76 \\ LHMC EF269 \\ LHMC EF 1006 \\ LHMC AM 172
}

c Actinomyces viscosus ATCC 15987 (1)

92 HIK A. viscosus

A. viscosus WVU 440

333 HIK A $902 / 74$

A. viscosus ATCC 19246 (2)

A. viscosus E Be66

A. viscosus $\mathrm{E} \mathrm{Be} 32$

84 HIK A $360 / 75$

A. viscosus ATCC 27044 (WVU 474)

A. viscosus LHMC B25

A. viscosus LHMC $8 \mathrm{A06}$

A. viscosus LHMC $11 \mathrm{~B} 2$

A. naeslundii WVU 820

$A$. naeslundii LHMC B 120 (3)

A. naeslundii LHMC B 102 (3)

A. viscosus LHMC B236

101 HIK A 754/74

298 HIK A $141 / 77$

66i HIK A $292 / 75$

66ii HIK A 292/75

64 HIK A $181 / 75$

Poland 22

A. viscosus E Be64

LHMC AC2165

90 HIK A $510 / 76$

\section{Origin}

Pus, jaw cyst

Pus, chin abscess

Human actinomycosis

Pus

Pus, extraoral incision

Pus, jaw lesion (sinusitis)

Oral isolate, child

Source not known

Source not known

Pus, intraoral incision

Human source

Pus, extraoral incision

Human sinus after extraction

Source not known

Source not known

Sputum

Human dental calculus

Swab, throat phlegmon

Source not known

Intraoral incision

Human source

Wound abscess

Intraoral incision, jaw

Human source

ATCC

Human dental calculus

Pus, perimandibular abscess

Throat abscess

Pus, jaw

Oral isolate, child

Oral isolate, child

Oral isolate, child

Periodontal disease, hamster

ATCC

Hamster mouth

Human source

Cervico-facial actinomycosis

Human carious dentine

Human carious dentine

Pus, cheek incision

Human sputum

Dental plaque, child

Dental plaque, New Guinea tribesman

Dental plaque, New Guinea tribesman

Human source

Approximal plaque, child

Approximal plaque, child

Dental plaque, child

Throat swab

Wound abscess

Pus, cheek abscess

Pus, cheek abscess

Pus, periodontitis, perimandibular

Human source

Human carious dentine

Oral isolate, child

Cheek abscess 
Table 1 (continued)

\begin{tabular}{|c|c|c|c|}
\hline Cluster & $\begin{array}{l}\text { Sub- } \\
\text { cluster }\end{array}$ & Strain name/number* & Origin \\
\hline \multicolumn{2}{|c|}{ Not clustered } & $\begin{array}{l}\text { LHMC AC3136 } \\
\text { Poland } 19\end{array}$ & $\begin{array}{l}\text { Oral isolate, child } \\
\text { Human source }\end{array}$ \\
\hline \multicolumn{2}{|l|}{4} & $\begin{array}{l}74 \text { HIK A } 662 / 76 \\
263 \text { HIK A } 481 / 75 \\
319 \text { HIK A } 382 / 77 \\
347 \text { HIK }\end{array}$ & $\begin{array}{l}\text { Intraoral incision } \\
\text { Pus, gum wound, jaw } \\
\text { Source not known } \\
\text { Source not known }\end{array}$ \\
\hline \multicolumn{2}{|c|}{ Not clustered } & $\begin{array}{l}292 \text { HIK A } 27 / 77 \\
\text { LHMC AC } 1972 \\
293 \text { HIK A } 67 / 77 \\
\text { LHMC AM } 442 \\
85 \text { HIK A } 402 / 75 \\
264 \text { HIK A } 509 / 75 \\
335 \text { HIK } \\
287 \text { HIK A } 615 / 76 \\
290 \text { HIK A } 685 / 76 \\
71 \text { HIK A } 421 / 76\end{array}$ & $\begin{array}{l}\text { Source not known } \\
\text { Oral isolate, child } \\
\text { Pus, extraoral incision } \\
\text { Oral isolate, child } \\
\text { Pus, extraoral chronic process } \\
\text { Pus, cheek abscess } \\
\text { Source not known } \\
\text { Preauricular abscess } \\
\text { Abscess after tooth extraction } \\
\text { Intraoral incision, jaw }\end{array}$ \\
\hline \multirow[t]{3}{*}{5} & $\mathbf{a}$ & $\begin{array}{l}\text { Bifidobacterium bifidum NCTC } 10471 \\
\text { Bifidobacterium bifidum NCTC } 10472\end{array}$ & $\begin{array}{l}\text { Stool } \\
\text { Stool }\end{array}$ \\
\hline & b & $\begin{array}{l}271 \text { HIK A } 110 / 76 \\
272 \text { HIK A } 159 / 76 \\
282 \text { HIK A } 457 / 76\end{array}$ & $\begin{array}{l}\text { Pus, extraoral incision } \\
\text { Pus, extraoral incision } \\
\text { Granuloma, median neck incision }\end{array}$ \\
\hline & c & $\begin{array}{l}\text { Eubacterium lentum ATCC } 25559 \\
\text { Eu. alactolyticum ATCC } 23263\end{array}$ & $\begin{array}{l}\text { Rectal tumour } \\
\text { Purulent pleurisy }\end{array}$ \\
\hline \multicolumn{2}{|l|}{6} & $\begin{array}{l}\text { Eu. limosum ATCC } 8486 \\
\text { Eu. ventriosum ATCC } 27560\end{array}$ & $\begin{array}{l}\text { Source not known } \\
\text { Faeces }\end{array}$ \\
\hline \multicolumn{2}{|c|}{ Not clustered } & Eu. contortum ATCC 25540 & Gangrenous appendicitis \\
\hline \multicolumn{2}{|l|}{7} & $\begin{array}{l}\text { Actinomyces bovis ATCC } 13683 \text { (1) } \\
\text { A. bovis ATCC } 13683(1) \\
95 \text { HIK A. bovis }\end{array}$ & $\begin{array}{l}\text { Bovine lumpy jaw } \\
\text { Bovine lumpy jaw } \\
\text { Source not known }\end{array}$ \\
\hline \multicolumn{2}{|l|}{8} & $\begin{array}{l}\text { Bifidobacterium bifidum ATCC } 17930 \\
149 \text { HIK A } 595 / 74\end{array}$ & $\begin{array}{l}\text { Source not known } \\
\text { Source not known }\end{array}$ \\
\hline \multicolumn{2}{|l|}{9} & $\begin{array}{l}\text { Actinomyces bovis CDC W1755 (2) } \\
\text { Erysipelothrix rhusiopathiae NCTC } 8163 \\
\text { E. rhusiopathiae L C } 220 \\
\text { E. rhusiopathiae L C } 218 \\
\text { E. rhusiopathiae L C } 219 \\
\text { E. rhusiopathiae L C } 221 \\
198 \text { HIK Corynebacterium pyogenes }\end{array}$ & $\begin{array}{l}\text { Bovine lumpy jaw } \\
\text { Spleen of pig with endocarditis } \\
\text { Human source } \\
\text { Human source } \\
\text { Human source } \\
\text { Human source } \\
\text { Source not known }\end{array}$ \\
\hline \multicolumn{2}{|l|}{10} & $\begin{array}{l}\text { Corynebacterium pyogenes NCTC } 6448 \\
\text { C. pyogenes NCTC } 6450 \\
\text { C. pyogenes NCTC } 5224 \\
\text { C. pyogenes NCTC } 5225 \\
\text { C. pyogenes MAFF C } 140 \\
\text { C. pyogenes MAFF C } 143 \\
\text { C. pyogenes MAFF C } 110 \\
\text { C. pyogenes MAFF P16 } \\
\text { C.pyogenes MAFF P } 18 \\
\text { C.pyogenes MAFF C } 106\end{array}$ & $\begin{array}{l}\text { Source not known } \\
\text { Source not known } \\
\text { Pig } \\
\text { Pig } \\
\text { Bovine foot infection } \\
\text { Bovine mastitis } \\
\text { Bovine mastitis } \\
\text { Vaginal discharge, pig } \\
\text { Hock joint, piglet } \\
\text { Source not known }\end{array}$ \\
\hline \multicolumn{2}{|l|}{11} & $\begin{array}{l}\text { Actinomyces odontolyticus ATCC } 17929 \text { (1) } \\
\text { A. odontolyticus ATCC } 17982 \text { (1) } \\
\text { A. odontolyticus CDC W } 1514 \text { (2) } \\
107 \text { HIK A } 543 / 77 \\
320 \text { HIK A } 570 / 77\end{array}$ & $\begin{array}{l}\text { Carious tooth lesion } \\
\text { Carious tooth lesion } \\
\text { Dental plaque } \\
\text { Pus, abscess } \\
\text { Pus }\end{array}$ \\
\hline \multicolumn{2}{|c|}{ Not clustered } & Actinobacterium meyerii H 8619 & Source not known \\
\hline
\end{tabular}


Table 1 (continued)

Sub-

Cluster cluster Strain name/number* $\quad$ Origin

12 Corynebacterium haemolyticum NCTC 9697 Source not known

C. haemolyticum NCTC $9998 \quad$ Source not known

C. haemolyticum NCTC $8452 \quad$ Pig

a Arachnia propionica ATCC 14157 (1)

Ar. propionica 'Fleischmann' (1)

118 HIK A $58 / 75$

119 HIK A $55 / 76$

116 HIK A $313 / 74$

Ar. propionica ATCC 29324 (1)

b 110 HIK Ar. propionica

Ar. propionica ATCC 29326 (2)

112 HIK

194 HIK

300 HIK A $262 / 77$

265 HIK A $570 / 75$

288 HIK A $617 / 76$

278 HIK

267 HIK A $37 / 76$

Lacrimal canaliculitis

Cervico-facial actinomycosis

Cyst contents, jaw

Pus, submucous abscess

Pus

Cervico-facial actinomycosis

Source not known

Human actinomycosis

Source not known

Source not known

Intraoral swab

Pus, extraoral incision

Sputum

Source not known

Pus, extraoral incision

Bacterionema matruchotii ATCC 14266

B. matruchotii ATCC 14266

Source not known

Source not known

128 HIK A 4/76

123 HIK Bacterionema

124 HIK A 301/73

B. matruchotii NCTC 10254

127 HIK A $611 / 75$

130 HIK A $72 / 77$

129 HIK A $29 / 76$

Not clustered LHMC H341/77

Agromyces ramosus ATCC 25173

Actinobacillus sp. ATCC 27072

Rothia dentocariosa ATCC 17931 (1)

R. dentocariosa v.d.H. B22

$R$. dentocariosa CDC W808 (2)

b $\quad R$. dentocariosa v.d.H. B25

$\boldsymbol{R}$. dentocariosa v.d.H. B28

$R$. dentocariosa v.d.H. B29

$R$. dentocariosa ATCC 14189

Pus, subcutaneous abscess

Source not known

Extraoral incision (broken jaw)

Source not known

Pus

Pus

Sputum

Source not known

Soil

Vaginal discharge, pig

Carious teeth, human

Human mouth

Carious teeth

Human mouth

Human mouth

Human mouth

Carious teeth

Propionibacterium freudenreichii subsp.

freudenreichii NCIB 5959

$P$. freudenreichii subsp. freudenreichii

NCIB 8896

$P$. freudenreichii subsp. shermanii NCIB 8099

P. acnes ATCC 6919

$P$. acnes ATCC 11828

$P$. avidum ATCC 25577

$P$. avidum $\mathrm{Cu} 0589$

$P$. freudenreichii subsp. shermanii NCIB 5968

Source not known

Source not known

Source not known

Facial acne

Subcutaneous abscess

Source not known

Source not known

Source not known

Source not known

Source not known

$$
\begin{aligned}
& \text { P. jensenii NCIB } 5960 \\
& P \text {. jensenii NCIB } 8069 \\
& P \text {. lymphophilum ATCC } 27520
\end{aligned}
$$

\author{
Cheese \\ Cheese \\ Submaxillary tissue
}


Table 1 (continued)

$\begin{array}{clll}\text { Cluster } & \begin{array}{c}\text { Sub- } \\ \text { cluster }\end{array} & \text { Strain name/number* } & \\ 22 & & \text { P. thoenii NCIB } 5966 & \text { Cheese } \\ & & P \text {. thoenii NCIB } 8072 & \text { Cheese }\end{array}$

* Figures in parentheses indicate serotypes.

Sources: ATCC, American Type Culture Collection, Rockville, Maryland, U.S.A.; CDC, Communicable Disease Center, Atlanta, Georgia, U.S.A.; Cu, Dr C. S. Cummins, Virginia Polytechnic Institute, Blacksburg, Virginia, U.S.A.; E, Dr S. E. Edwardson, University of Lund, Sweden; H, received from Dr K. Holmberg, National Bacteriological Laboratory, Stockholm, Sweden; v.d.H., Dr H. van der Heremer, University of Nijmegen, The Netherlands; HIK, isolated in the Hygiene Institute, University of Cologne, F.R.G.; L, received from Dr D. Jones, University of Leicester, U.K.; LHMC, MRC Dental Epidemiology Unit, London Hospital Medical College, U.K.; MAFF, received from Ministry of Agriculture, Fisheries and Food, Thirsk, Yorkshire, U.K.; NCDO, National Collection of Dairy Organisms, Reading, U.K.; NCIB, National Collection of Industrial Bacteria, Aberdeen, U.K.; NCTC, National Collection of Type Cultures, London, U.K.; Poland, received from Dr P. Heczko, Institute of Microbiology, Medical Academy, Cracow, Poland; Spain, received from Dr A.-C. Velasco, Servicio de Microbiologia, C.S.S.S., Carretera de Andalucia, Madrid, Spain; WVU, West Virginia University, Morgantown, West Virginia, U.S.A.

ensure even distribution of the insoluble substances. The plates were inoculated from suspensions of the bacteria in thioglycollate broth (TB; Becton Dickinson, 11727) and were examined after $21 \mathrm{~d}$ incubation.

Hydrogen sulphide production. Slopes of Kligler iron agar (Oxoid, CM33) were stab inoculated from $7 \mathrm{~d}$ cultures on BHIA. After incubation for 7 and $14 \mathrm{~d}$, the tubes were examined for blackening of the medium.

Sodium chloride and bile tolerance. Bacteria were inoculated into $2 \mathrm{ml}$ of BHIB plus 2,4 or $6 \%(\mathrm{w} / \mathrm{v}) \mathrm{NaCl}$ and into BHIB with bile salts (Merck, 4054) at a concentration of 5,10 or $20 \%$ (w/v). A control of BHIB only was also included. All inoculations were made from bacterial suspensions in BHIB adjusted to an absorbance at $578 \mathrm{~nm}\left(A_{578}\right)$ of 1.0 . After $7 \mathrm{~d}$ incubation, the tubes were examined for growth.

Inhibition by potassium tellurite, sodium azide, sodium selenite, sodium taurocholate and crystal violet. BHIA was used with the inhibitors added from pre-sterilized solutions to give final concentrations of $0.01 \%(\mathrm{w} / \mathrm{v})$ potassium tellurite, $0.005 \%(\mathrm{w} / \mathrm{v})$ sodium azide, $0.01 \%(\mathrm{w} / \mathrm{v})$ sodium selenite, $0.2 \%(\mathrm{w} / \mathrm{v})$ sodium taurocholate and $0.005 \%(\mathrm{w} / \mathrm{v})$ crystal violet. It had been established that these concentrations gave rise to differential responses.

Sensitivity to antibiotics. Petri dishes containing a basal layer of $10 \mathrm{ml}$ of iso-sensitest agar (Oxoid, CM471) were overlaid with $9.9 \mathrm{ml}$ of cooled sterile iso-sensitest agar which had been inoculated with $0.1 \mathrm{ml}$ of bacterial suspension. These suspensions were prepared in TB from $4 \mathrm{~d}$ cultures and were adjusted to an $A_{578}$ of 1.5. Immediately after solidification of the agar, antibiotic-containing discs (Sensi-Discs; Becton Dickinson) were placed on the agar surface (4 discs per plate; 16 different antibiotics). The plates were checked for the presence or absence of inhibition zones after 2 and $4 \mathrm{~d}$ incubation, any sign of inhibition being recorded as positive. Therefore the results cannot be used for clinical purposes.

Susceptibility to lysozyme. Bacteria grown for $7 \mathrm{~d}$ on CC agar were suspended in $0.4 \mathrm{ml}$ of sterile distilled water at an $\boldsymbol{A}_{378}$ of 1.0 . The suspension was divided into four parts; to two parts were added $0.5 \mathrm{ml}$ of a $1.0 \%(\mathrm{w} / \mathrm{v})$ solution of lysozyme (Oxoid) in buffer, and to the other two, $0.5 \mathrm{ml}$ of distilled water. The tubes were incubated at $37^{\circ} \mathrm{C}$. After $4 \mathrm{~h}$, one tube containing lysozyme and one control were removed and examined for clearing and for the appearance of a glutinous mass. Both tubes were then shaken and $0.5 \mathrm{ml}$ of $20 \%(\mathrm{w} / \mathrm{v})$ sodium dodecyl sulphate (SDS) were added; any decrease in turbidity or a total clearing of the suspension was recorded (Mordarska et al., 1978). This was repeated after $24 \mathrm{~h}$ on the duplicate set of tubes.

Haemolysis of blood. Haemolysis ( $\alpha$ or $\beta$ ) of human, horse, rabbit and sheep blood was tested by incorporating $0.5 \%(\mathrm{v} / \mathrm{v})$ whole blood into BHIA. Examination was at 7 and $14 \mathrm{~d}$ after inoculation.

Production of acid from carbohydrates. The methods used were those described by Schofield \& Schaal (1979, 1980a).

Aesculin hydrolysis. Commercially prepared 'discs' were used (Becton Dickinson, 25024) and inoculated at the same time as the sugar 'discs', which were used for determination of acid production. A deep brown-black colour in the 'disc' after $4 \mathrm{~d}$ incubation indicated a positive result.

Deamination/decarboxylation of amino acids, urease activity, nitrate and nitrite reduction, production of indole. These tests were all performed as described by Schofield \& Schaal (1980 b).

End-products of glucose fermentation. The methods and column packing material were those described by Holdeman \& Moore (1972). 
API enzyme tests. The commercially prepared kits were from API Systems, Montalieu, Vercieu, France. Initial investigations were carried out using various growth media and preincubation times of the strains and periods of incubation of the strips, to determine the conditions which gave best reproducibility. Bacteria were transferred from BHIA to CC agar and after $7 \mathrm{~d}$ incubation were suspended in sterile distilled water to an $A_{378}$ of $1.5 ; 2$ drops from a standard pasteur pipette were placed into each well. The strips were incubated at $37^{\circ} \mathrm{C}$ for $6 \mathrm{~h}$ before being tested with the reagents provided. The strips were then left exposed to normal daylight for 30 min before the colours were compared with the charts provided. Only those colours showing a colour code of 3 or above were recorded as positive.

All tests were repeated twice.

Coding of the characters. All characters were coded in one of two mutually exclusive states and were scored 1 or 0 , giving a total of 124 binary variables for computation, excluding all characters which showed $100 \%$ agreement.

Computation. The clustan 1C package of Wishart (1978) was employed. The unweighted pair group average linkage method (Sokal \& Michener, 1958) was used in all analyses, single linkage having previously been found to produce 'chaining' effects. The simple matching coefficient $\left(S_{S M}\right)$ (Sokal \& Michener, 1958) and the similarity coefficient of Jaccard $\left(S_{j}\right)$ (Sneath, 1957) were used together with pattern $\left(D_{p}\right)$ (Sneath, 1968), shape, size and error sum of squares statistics.

\section{RESULTS}

At $82.5 \%$ similarity $\left(S_{S_{M}}\right)$ with average linkage clustering, most strains fell into one of 22 principal clusters. These were defined as containing at least one reference culture and/or more than three strains. Clusters composed of only two or three isolates without reference cultures were not considered in analyses of the results. All but one (cluster 4) of the principal clusters were recovered when using any one of the other coefficients, and variation in their internal structure was slight. As it was not possible to give strain labels in the figures, these are listed in Table 1 in the order in which they occur in the unabridged dendrogram (Fig. 1).

The detailed analysis of the results was mainly based upon the simple matching coefficient, $S_{S M}$ (Fig. 1). For comparison, however, abbreviated dendrograms prepared from both the $S_{J}$ and $D_{P}$ analyses are also given (Figs 2 and 3). Since the $S_{J}$ analysis excludes negative matches, groupings solely due to negative correlations would be uncovered, but the number of strains giving predominantly negative test responses was small and constituted only $0.6 \%$ of the total number of organisms. The $D_{p}$ coefficient reduces the influence of different cell generation rates and sizes (Sneath, 1968). Because members of various genera in several families were included in the study this coefficient might provide valuable additional information. Major discrepancies in the cluster compositions obtained using the three coefficients are discussed below together with the description of the respective clusters. In general, clusters formed at $60 \% S_{\text {J }}$ and $90 \% D_{P}$ were equivalent to those at $82.5 \% S_{S M}$.

Cluster 1 contained 59 strains. All except one were previously designated Actinomyces israelii; the exception, Cologne isolate HIK68, was originally identified as Actinomyces naeslundii. The phenon separated into four subclusters at $84.5 \% S_{S M}$ (Fig. 1). Subclusters a and $\mathrm{b}$ contained several reference cultures and recent isolates, many previously identified as serotypes 1 or 2 . No reference strains were recovered in subclusters $c$ and d, and most of these isolates had not been successfully serotyped in our laboratory. On the edge of this cluster there appeared several strains which are at present uncertainly classified. One such strain was $A$. naeslundii WVU 963, which has been considered to be $A$. israelii (M. A. Gerencser, personal communication) or to be associated with $A$. naeslundii and $A$. viscosus (E. Fillery, personal communication). Cluster composition was the same with the $S_{J}$ and $D_{P}$ coefficients but subgroups a and c were amalgamated with the $S_{J}$ analysis.

Cluster 2 consisted of the only two Lactobacillus strains included in the study, L. casei subsp. rhamnosus and $L$. plantarum, which were linked at $91 \% S_{S M}$.

Cluster 3 was composed of 46 strains mostly designated $A$. naeslundii or $A$. viscosus. At $84.5 \% S_{S M}$ it was separated into three subclusters. Subcluster a contained: two strains of $A$. naeslundii serotype 1, WVU 398A being duplicated as one culture was received from the London Hospital Medical College (LHMC) and one directly from WVU; $A$. naeslundii 


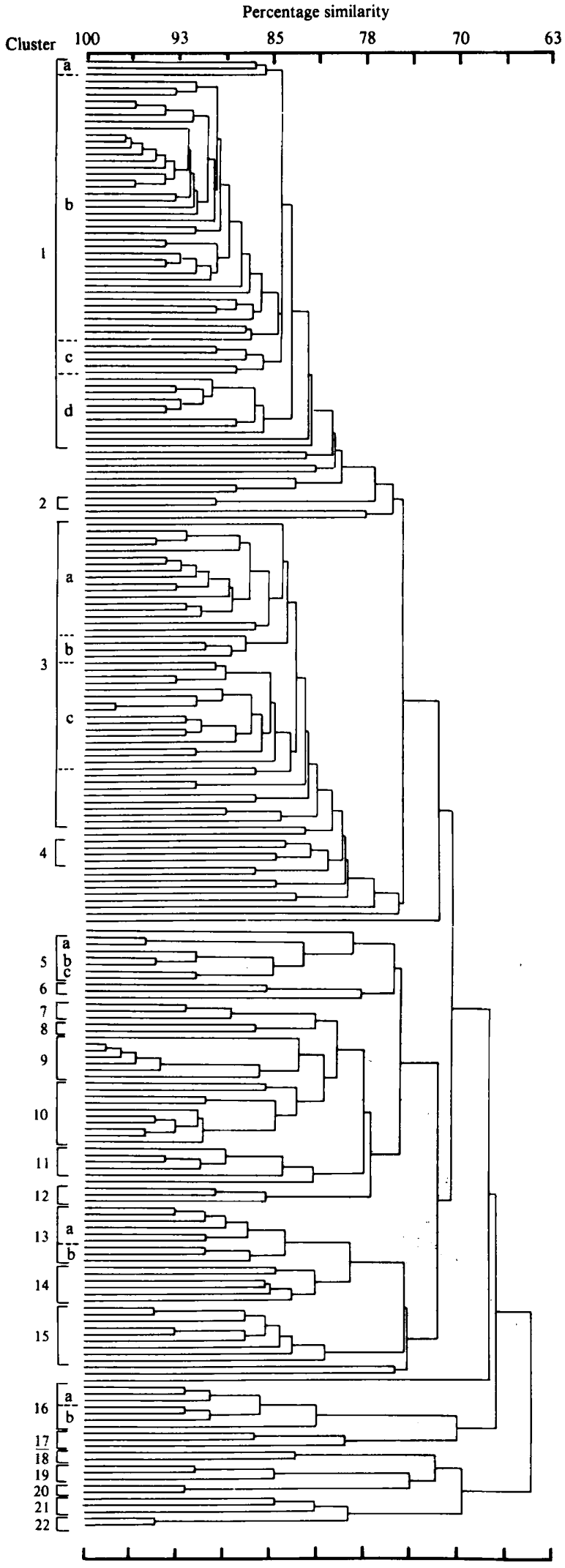

Fig. 1. Dendrogram showing similarity between strains based on the $S_{S M}$ coefficient and average linkage. 


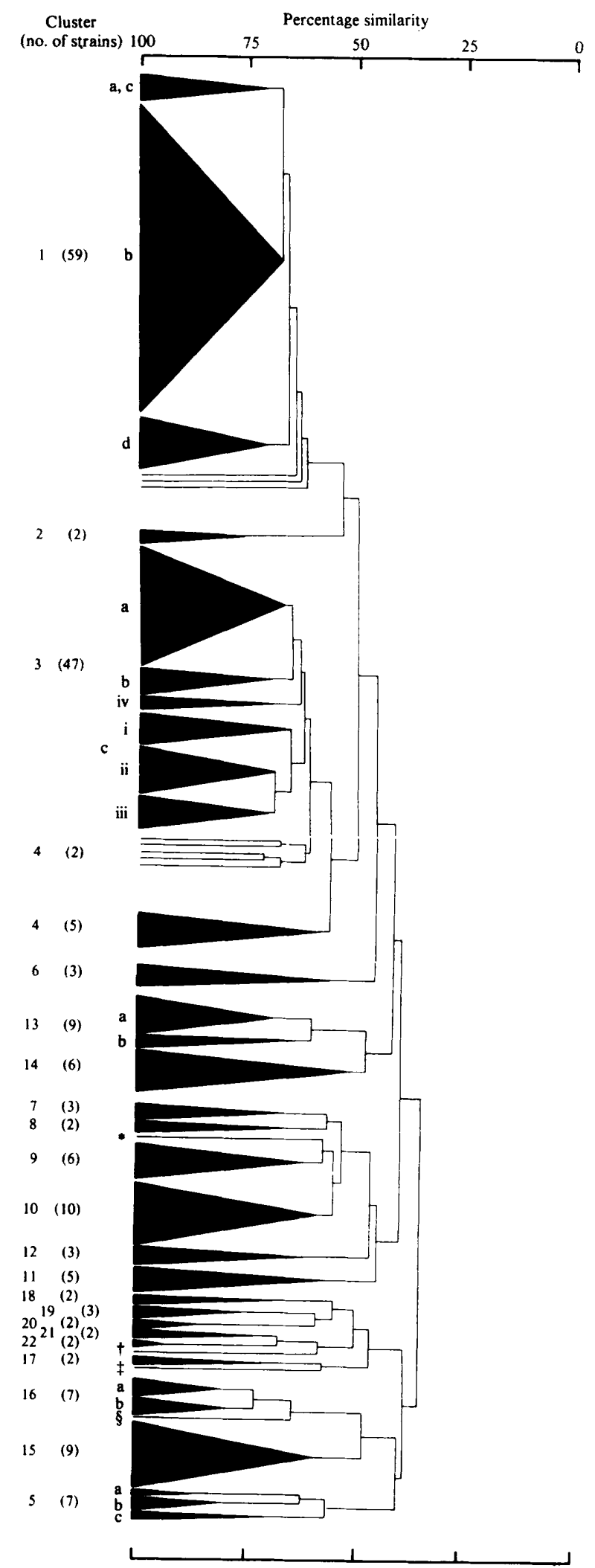

Fig. 2. Abbreviated dendrogram showing similarity between strains based on the $S_{J}$ coefficient and average linkage.

Single strains: $\quad$ * CDC W1755: + ATCC 27520: $\quad \ddagger$ NCIB 8099: $\S$ ATCC 14189 . 


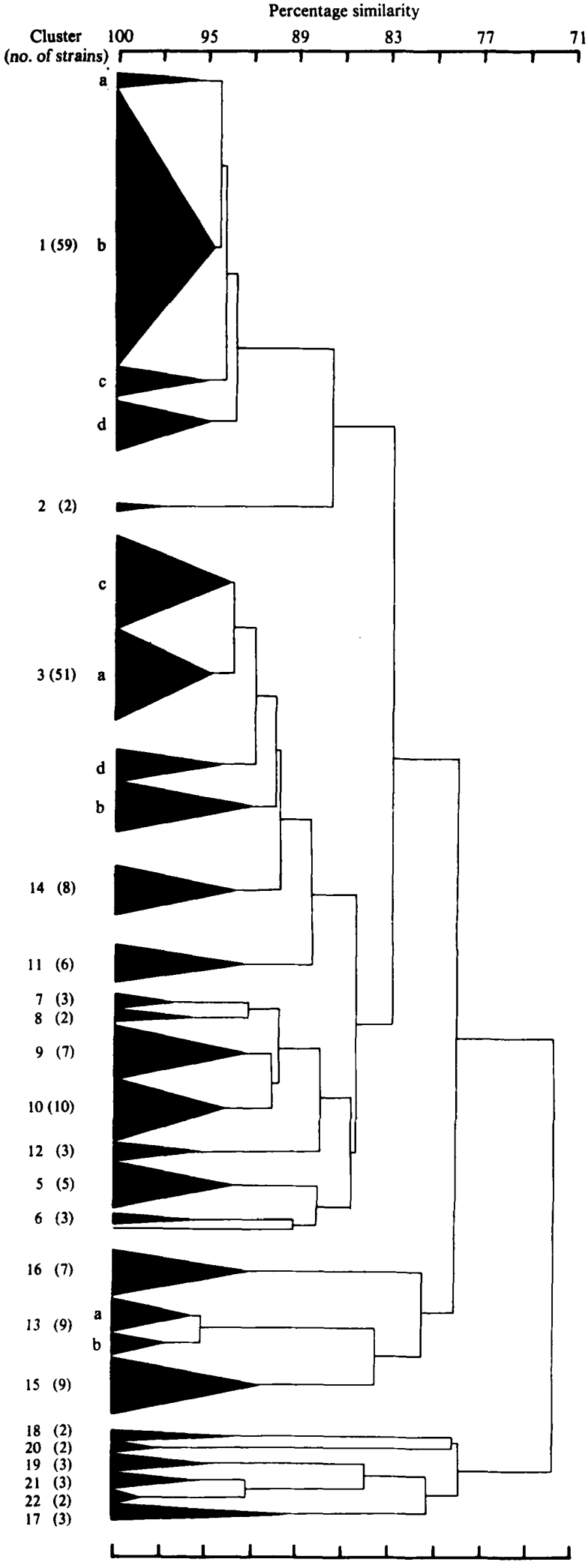

Fig. 3. Abbreviated dendrogram showing similarity between strains based on the pattern coefficient $\left(D_{p}\right)$ and average linkage. 
serotype 2 CDC W752; several old reference cultures of $A$. naeslundii from the Cologne collection, and seven recent isolates. At $86 \% S_{S M}$, two isolates labelled $A$. viscosus (HIK 86, HIK91) were linked to this $A$. naeslundii subcluster. Subcluster b contained one HIK strain (unidentified) and three oral isolates from young children (LHMC). The majority of subcluster c strains were labelled $A$. viscosus and these fell into one of four smaller subgroups at $88 \% S_{S M}$. One of these small subgroups (i) consisted of $A$. viscosus serotype 1 plus two HIK isolates and WVU 440; this group linked at approximately $85 \% S_{S M}$ with the other three subgroups. Subgroup ii contained $A$. viscosus serotype 2 , two strains from carious dentine and one HIK strain; subgroup iii consisted of four so-called 'atypical' strains of $A$. viscosus (ATCC 27044, B25, 8A06, 11B2) and $A$. naeslundii WVU 820. Completing subcluster c were the two serotype 3 strains of $A$. naeslundii (B120 and B102) forming subgroup iv, together with an $A$. viscosus strain. The remaining nine strains in cluster 3 were recent isolates of oral origin. Some of these fell into small subgroups at $84.5 \% S_{S M}$, all consisting of only two strains. Alterations to the cluster occurred with the $S_{J}$ and $D_{P}$ coefficients. Using $S_{J}$, subgroup c (iv) linked directly to subgroup a. With $D_{p}$, subgroup b was enlarged with two additional strains from the periphery of cluster 3 and was joined by cluster 4; furthermore, a new subgroup $d$ was formed.

Cluster 4 consisted of only four HIK isolates and occurred on the edge of the $A$. naeslundii/A. viscosus cluster. Although sharing many characters in common with phenon 3 , the strains in cluster 4 differed in several respects from $A$. naeslundii/A. viscosus isolates. These included lack of growth under aerobic conditions, more filamentous appearance, hydrolysis of starch, acid production from amygdalin, little or no activity with meso-inositol, lactose, melibiose or ribose, tolerance to $4 \%(\mathrm{w} / \mathrm{v}) \mathrm{NaCl}$, absence of lysis by lysozyme after $4 \mathrm{~h}$, and lack of acid phosphatase (Table 2). A relatively large number of isolates, mostly from HIK and LHMC, and which had previously proved difficult to identify, fell on the peripheries of clusters 3 and 4 . Using the $S_{J}$ coefficient, two strains were removed to cluster 3 , and two isolates which had joined at $81 \%$ to cluster 4 and one unclustered isolate were linked with the two remaining strains of cluster 4 .

Clusters 5 and 6 . Three distinct subclusters were linked at the relatively low similarity level of $83 \%$ in cluster 5 . Two Bifidobacterium bifidum reference cultures joined at $97 \% S_{S M}$ into one subgroup (a), three of the recent HIK isolates formed the second subgroup (b), and two of the five cultures of Eubacterium included in the study constituted the third subgroup (c). Two of the remaining three strains of Eubacterium formed cluster 6 and were joined at $78 \%$ $S_{S M}$ by the third. With the $S_{J}$ coefficient, cluster 5 moved its relative position and linked at only $39 \% S_{J}$ to clusters 15 and 16 . Also at $60 \% S_{J}$, the subclusters of cluster 5 could be considered as three separate clusters.

Cluster 7 consisted of a duplicated culture of the reference strain of Actinomyces bovis ATCC 13683 serotype 1 and one old reference strain from the Cologne collection.

Cluster 8 contained the Bifidobacterium bifidum strain ATCC 17930 and one HIK isolate, and was linked to cluster 7 at $81 \% S_{S M}$.

Cluster 9 was composed of one culture of $A$. bovis serotype 2 (CDC W1755), plus a discrete group of all of the strains of Erysipelothrix rhusiopathiae included in the study and one recent HIK isolate, which had been tentatively identified as Corynebacterium pyogenes. This group linked to the $A$. bovis strain at a relatively low similarity level. The $A$. bovis strain was removed from cluster 9 by the $S_{J}$ coefficient.

Cluster 10 comprised four reference cultures of Corynebacterium pyogenes and six recent isolates all of which were labelled Corynebacterium pyogenes.

Cluster 11 contained five strains, three of which were reference cultures of Actinomyces odontolyticus, the others being HIK isolates. The single culture of Actinobacterium meyerii included in the study linked to this cluster at $82 \% S_{S M}$.

Cluster 12 was formed by a small group of three reference cultures of Corynebacterium haemolyticum. 
Table 2. Characteristics of strains contained in major phena as percentages of positive reactions

Reference

cultures associated with phenon

No. of strains

Cluster no.

Colony rough

Colony smooth

Gram-positive

Gram-variable

Cells filamentous

Cells diphtheroidal

Aerobic growth

Enhanced growth with

increased $\mathrm{CO}_{2}$

Anaerobic growth

(absence of $\mathrm{CO}_{2}$ )

Cytochrome oxidase:

pale blue

deep blue

Catalase

$\mathrm{NO}_{2}^{-}$reduction

$\mathrm{NO}_{3}^{-}$reduction

DNAase

Indole

Hydrolysis tests:

aesculin

gelatin

starch

casein

Tween 20

Tween 40

Tween 60

Tween 80

lecithinase

lipase - egg yolk

Alkali produced in peptone-

containing media

Acid from:

arabinose

adonitol

amygdalin

cellobiose

dulcitol

dextrin

iso-erythritol

meso-erythritol

fructose

galactose

glucose

glycerol

meso-inositol

lactose

mannitol

mannose

maltose

melibiose

melezitose

raffinose

rhamnose

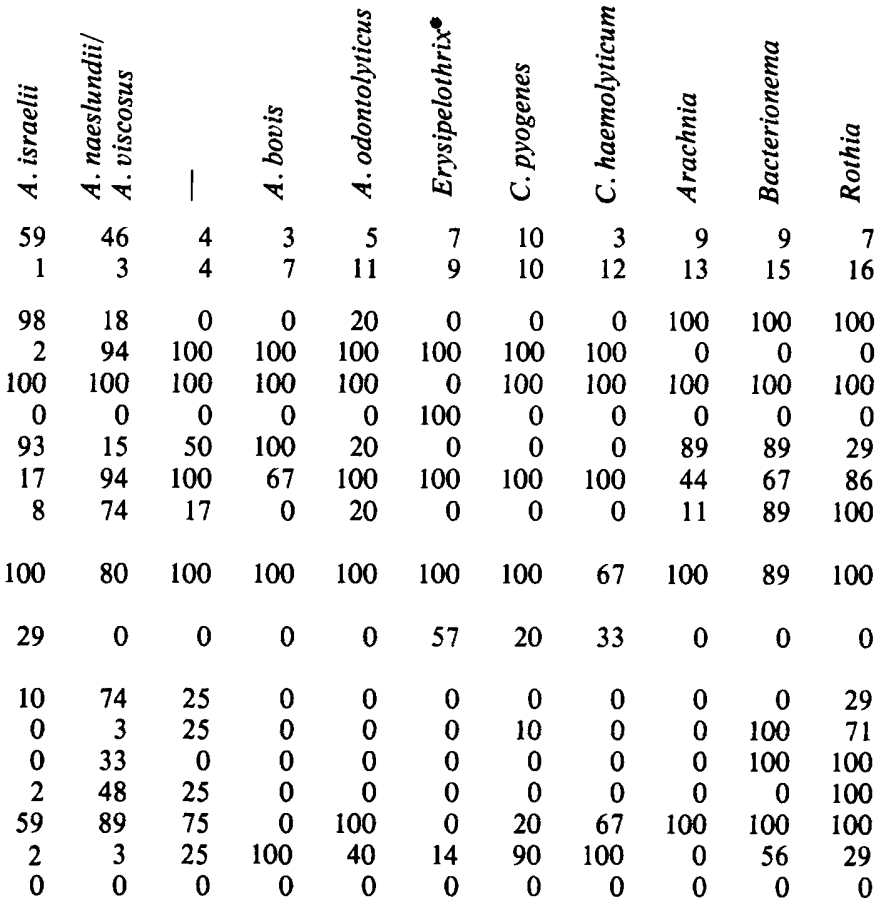

$\begin{array}{rrrrrrrrrrr}98 & 61 & 100 & 0 & 20 & 0 & 0 & 0 & 0 & 0 & 86 \\ 10 & 2 & 0 & 0 & 0 & 0 & 20 & 0 & 11 & 33 & 43 \\ 12 & 24 & 75 & 100 & 60 & 0 & 50 & 67 & 11 & 89 & 0 \\ 1 & 0 & 0 & 0 & 0 & 0 & 90 & 0 & 0 & 11 & 0 \\ 0 & 0 & 0 & 0 & 0 & 0 & 0 & 0 & 0 & 0 & 0 \\ 58 & 35 & 25 & 0 & 0 & 0 & 20 & 100 & 0 & 33 & 57 \\ 59 & 28 & 0 & 0 & 0 & 0 & 10 & 67 & 11 & 57 & 57 \\ 0 & 0 & 0 & 0 & 20 & 0 & 10 & 0 & 0 & 0 & 0 \\ 17 & 2 & 0 & 0 & 0 & 0 & 10 & 33 & 0 & 0 & 0 \\ 3 & 2 & 0 & 0 & 0 & 0 & 10 & 33 & 33 & 0 & 0\end{array}$

$\begin{array}{lllllllllll}1 & 2 & 0 & 0 & 0 & 14 & 10 & 100 & 0 & 100 & 100\end{array}$

$\begin{array}{rrrrrrrrrrr}54 & 5 & 25 & 0 & 60 & 0 & 20 & 0 & 44 & 11 & 14 \\ 3 & 0 & 0 & 0 & 20 & 0 & 10 & 33 & 56 & 0 & 0 \\ 90 & 7 & 25 & 0 & 0 & 0 & 0 & 0 & 89 & 0 & 0 \\ 87 & 36 & 50 & 0 & 0 & 0 & 0 & 0 & 0 & 0 & 0 \\ 2 & 0 & 0 & 0 & 0 & 0 & 0 & 0 & 0 & 0 & 0 \\ 97 & 87 & 75 & 67 & 80 & 0 & 60 & 100 & 67 & 0 & 0 \\ 2 & 0 & 0 & 0 & 0 & 0 & 0 & 0 & 0 & 0 & 0 \\ 8 & 6 & 0 & 0 & 0 & 0 & 0 & 0 & 11 & 0 & 0 \\ 100 & 89 & 100 & 100 & 100 & 100 & 90 & 67 & 100 & 100 & 100 \\ 95 & 95 & 75 & 100 & 20 & 86 & 90 & 67 & 89 & 56 & 14 \\ 100 & 100 & 100 & 100 & 100 & 100 & 100 & 100 & 100 & 100 & 100 \\ 8 & 31 & 0 & 100 & 0 & 0 & 0 & 0 & 56 & 0 & 14 \\ 91 & 76 & 0 & 67 & 0 & 0 & 0 & 0 & 22 & 0 & 0 \\ 91 & 80 & 25 & 100 & 60 & 86 & 100 & 100 & 89 & 22 & 14 \\ 81 & 4 & 0 & 0 & 0 & 14 & 0 & 0 & 89 & 33 & 0 \\ 93 & 80 & 75 & 0 & 0 & 14 & 50 & 67 & 89 & 67 & 71 \\ 98 & 98 & 75 & 67 & 80 & 14 & 80 & 33 & 89 & 33 & 100 \\ 95 & 74 & 25 & 67 & 0 & 0 & 0 & 0 & 11 & 0 & 0 \\ 80 & 44 & 0 & 0 & 0 & 0 & 30 & 0 & 11 & 0 & 57 \\ 100 & 94 & 50 & 0 & 0 & 0 & 0 & 0 & 100 & 0 & 0 \\ 36 & 2 & 0 & 0 & 60 & 0 & 0 & 0 & 0 & 0 & 0\end{array}$


Table 2 (continued)

\begin{tabular}{|c|c|c|c|c|c|c|c|c|c|c|c|}
\hline Cluster no. & 1 & 3 & 4 & 7 & 11 & 9 & 10 & 12 & 13 & 15 & 16 \\
\hline ribose & 100 & 52 & 0 & 0 & 0 & 100 & 90 & 23 & 11 & 78 & 0 \\
\hline sorbitol & 24 & 6 & 0 & 0 & 0 & 0 & 0 & 0 & 78 & 0 & 0 \\
\hline sucrose & 100 & 100 & 100 & 100 & 80 & 14 & 0 & 0 & 90 & 100 & 100 \\
\hline trehalose & 83 & 89 & 25 & 0 & 20 & 0 & 20 & 67 & 56 & 0 & 100 \\
\hline xylose & 93 & 14 & 25 & 0 & 40 & 0 & 70 & 0 & 0 & 0 & 14 \\
\hline$\alpha$-methyl-D-glucoside & 32 & 4 & 0 & 0 & 0 & 0 & 0 & 0 & 0 & 0 & 100 \\
\hline$\alpha$-methyl-D-mannoside & 12 & 7 & 0 & 0 & 0 & 14 & 0 & 33 & 0 & 0 & 0 \\
\hline \multicolumn{12}{|l|}{ Growth in the presence of: } \\
\hline $\mathrm{NaCl} 2 \%(\mathrm{w} / \mathrm{v})$ & 47 & 89 & 100 & 33 & 0 & 86 & 50 & 0 & 11 & 67 & 100 \\
\hline $4 \%(w / v)$ & 7 & 13 & 50 & 0 & 0 & 14 & 0 & 0 & 0 & 11 & 43 \\
\hline $6 \%(w / v)$ & 2 & 0 & 0 & 0 & 0 & 0 & 0 & 0 & 0 & 0 & 0 \\
\hline bile $5 \%(w / v)$ & 29 & 93 & 100 & 33 & 0 & 100 & 80 & 33 & 100 & 11 & 100 \\
\hline $10 \%(w / v)$ & 15 & 85 & 100 & 33 & 0 & 100 & 80 & 0 & 89 & 0 & 100 \\
\hline $20 \%(w / v)$ & 2 & 48 & 25 & 67 & 0 & 100 & 60 & 0 & 0 & 0 & 71 \\
\hline \multicolumn{12}{|l|}{ sodium selenite } \\
\hline $0.01 \%(w / v)$ & 10 & 31 & 0 & 33 & 0 & 14 & 0 & 0 & 56 & 78 & 100 \\
\hline \multicolumn{12}{|l|}{ potassium tellurite } \\
\hline $0.01 \%(w / v)$ & 47 & 61 & 50 & 100 & 20 & 71 & 50 & 0 & 33 & 0 & 100 \\
\hline \multicolumn{12}{|l|}{ sodium azide } \\
\hline $0.005 \%(w / v)$ & 91 & 85 & 100 & 33 & 100 & 100 & 100 & 0 & 89 & 100 & 100 \\
\hline \multicolumn{12}{|l|}{ crystal violet } \\
\hline $0.005 \%(w / v)$ & 8 & 19 & 25 & 33 & 0 & 86 & 0 & 33 & 11 & 22 & 0 \\
\hline sodium taurocholate $0.2 \%(\mathrm{w} / \mathrm{v})$ & 80 & 48 & 75 & 67 & 0 & 14 & 30 & 67 & 11 & 33 & 100 \\
\hline \multicolumn{12}{|l|}{$\begin{array}{l}\text { Growth characteristics on blood } \\
\text { agar: }\end{array}$} \\
\hline $\begin{array}{l}\text { human - grey/green discoloration } \\
\text { human - clearing and }\end{array}$ & 8 & 14 & 0 & 33 & 20 & 0 & 0 & 0 & 0 & 0 & 0 \\
\hline discoloration & 2 & 7 & 0 & 100 & 60 & 71 & 100 & 100 & 100 & 44 & 86 \\
\hline sheep - grey/green discoloration & 2 & 7 & 0 & 0 & 40 & 0 & 20 & 0 & 0 & 0 & 0 \\
\hline sheep - clearing and discoloration & 2 & 5 & 0 & 100 & 40 & 14 & 90 & 100 & 0 & 44 & 71 \\
\hline horse - clearing and discoloration & 0 & 3 & 0 & 67 & 40 & 29 & 100 & 100 & 67 & 11 & 29 \\
\hline \multicolumn{12}{|l|}{ Ammonia from: } \\
\hline arginine & 98 & 26 & 0 & 0 & 0 & 100 & 0 & 0 & 11 & 0 & 0 \\
\hline lysine & 0 & 2 & $\mathbf{0}$ & 0 & 0 & 0 & 0 & 0 & 0 & 0 & 14 \\
\hline ornithine & 2 & 0 & 0 & 0 & 0 & 0 & 0 & 0 & 0 & 0 & 29 \\
\hline serine & 0 & 0 & 0 & 0 & 0 & 0 & 0 & 0 & 56 & 11 & 100 \\
\hline alanine & 0 & 0 & 0 & 0 & 0 & 0 & 0 & 0 & 56 & 0 & 0 \\
\hline methionine & 0 & 0 & 0 & 0 & 0 & 0 & 0 & 0 & 11 & 0 & 14 \\
\hline aspartic acid & 2 & 5 & 0 & 0 & 0 & 0 & 0 & 0 & 22 & 56 & 14 \\
\hline glutamic acid & 0 & 0 & 0 & 0 & 0 & 0 & 0 & 0 & 22 & 11 & 0 \\
\hline leucine & 0 & 0 & 0 & 0 & 0 & 0 & 0 & 0 & 11 & 0 & 0 \\
\hline urea & 3 & 50 & 50 & 0 & 0 & 0 & 0 & 0 & 11 & 22 & 0 \\
\hline \multicolumn{12}{|l|}{ Decarboxylation of: } \\
\hline lysine & 0 & 0 & 0 & 0 & 20 & 0 & 0 & 0 & 0 & 44 & 0 \\
\hline ornithine & 0 & 0 & 0 & 0 & 0 & 0 & 0 & 0 & 44 & 33 & 0 \\
\hline methionine & 0 & 0 & 0 & 0 & 0 & 0 & 0 & 0 & 0 & 33 & 0 \\
\hline leucine & 0 & 0 & 0 & 0 & 0 & 14 & 0 & 0 & 0 & 0 & 29 \\
\hline aspartic acid & $\mathbf{0}$ & 0 & 0 & 0 & 0 & 14 & 0 & 0 & 0 & 22 & 0 \\
\hline glutamine & 2 & 0 & 0 & 0 & 0 & 0 & 0 & 0 & 0 & 0 & 14 \\
\hline \multicolumn{12}{|l|}{ Inhibition by ( $\mu \mathrm{g}$ per disc): } \\
\hline sulphamethoxazole trimethoprim & 32 & 65 & 75 & 33 & 40 & 86 & 70 & 100 & 11 & 67 & 14 \\
\hline $\begin{array}{l}\text { sulphamethoxazole trimethoprim } \\
(25)\end{array}$ & 32 & 89 & 75 & 33 & 80 & 100 & 90 & 100 & 11 & 89 & 100 \\
\hline amikacin $(10)$ & 95 & 100 & 100 & 100 & 80 & 100 & 100 & 100 & 89 & 100 & 86 \\
\hline cefoxitin (30) & 100 & 100 & 100 & 100 & 100 & 100 & 100 & 100 & 100 & 100 & 100 \\
\hline cline (30) & 98 & 98 & 100 & 100 & 100 & 100 & 100 & 0 & 100 & 100 & 86 \\
\hline Hyaluronidase & 2 & 2 & 0 & 0 & 20 & 0 & 0 & 0 & 11 & 11 & 72 \\
\hline Chondroitin sulphatase & 0 & 0 & 0 & 0 & 0 & 14 & 0 & 0 & 0 & 0 & 0 \\
\hline \multicolumn{12}{|l|}{ Lysis by lysozyme + SDS: } \\
\hline weak clearing, $4 \mathrm{~h}$ & 49 & 28 & 75 & 0 & 0 & 0 & 80 & 0 & 11 & 0 & 0 \\
\hline weak clearing, $24 \mathrm{~h}$ & 27 & 0 & 0 & 0 & 0 & 0 & 0 & 0 & 0 & 0 & \\
\hline strong clearing, $4 \mathrm{~h}$ & 3 & 63 & 0 & 100 & 100 & 100 & 20 & 0 & 0 & 78 & 100 \\
\hline strong clearing, $24 \mathrm{~h}$ & 71 & 100 & 100 & 100 & 100 & 100 & 100 & 100 & 100 & 100 & 100 \\
\hline
\end{tabular}


Cluster no.

End-products of glucose fermentation: acetic acid propionic acid butyric acid isovaleric acid caproic acid pyruvic acid lactic acid succinic acid API enzyme tests:

2. alkaline phosphatase

3. esterase (C4)

4. esterase lipase (C8)

5. lipase (C14)

6. leucine arylamidase

7. valine arylamidase

8. cystine arylamidase

10. chymotrypsin

11. acid phosphatase

12. phosphoamidase

13. $\alpha$-galactosidase

14. $\beta$-galactosidase

15. $\beta$-glucuronidase

16. $\alpha$-glucosidase

17. $\beta$-glucosidase

18. $N$-acetyl- $\beta$-glucosaminidase

19. $\alpha$-mannosidase

20. $\alpha$-fucosidase
Table 2 (continued)

$\begin{array}{rrrrrrrrrrr}1 & 3 & 4 & 7 & 11 & 9 & 10 & 12 & 13 & 15 & 16 \\ & & & & & & & & & & \\ 100 & 98 & 100 & 100 & 100 & 100 & 100 & 100 & 100 & 100 & 100 \\ 0 & 0 & 0 & 0 & 0 & 0 & 0 & 0 & 100 & 78 & 14 \\ 0 & 0 & 0 & 0 & 0 & 0 & 0 & 0 & 0 & 0 & 0 \\ 0 & 0 & 0 & 0 & 0 & 0 & 0 & 0 & 0 & 0 & 0 \\ 0 & 0 & 0 & 0 & 0 & 0 & 0 & 0 & 0 & 0 & 0 \\ 0 & 0 & 0 & 0 & 0 & 0 & 0 & 0 & 0 & 44 & 14 \\ 100 & 98 & 100 & 100 & 100 & 86 & 100 & 100 & 0 & 89 & 100 \\ 95 & 61 & 25 & 33 & 0 & 100 & 60 & 67 & 0 & 0 & 29 \\ & & & & & & & & & & \\ 2 & 0 & 0 & 0 & 0 & 0 & 0 & 33 & 0 & 11 & 0 \\ 64 & 26 & 0 & 0 & 0 & 0 & 10 & 0 & 89 & 100 & 43 \\ 7 & 6 & 0 & 0 & 0 & 0 & 10 & 0 & 100 & 100 & 43 \\ 3 & 2 & 25 & 0 & 0 & 0 & 0 & 0 & 0 & 0 & 0 \\ 83 & 93 & 50 & 100 & 100 & 29 & 20 & 0 & 78 & 0 & 100 \\ 1 & 9 & 0 & 0 & 0 & 0 & 0 & 0 & 0 & 0 & 71 \\ 0 & 0 & 0 & 0 & 0 & 0 & 0 & 0 & 0 & 0 & 86 \\ 0 & 0 & 0 & 0 & 0 & 71 & 0 & 0 & 0 & 0 & 0 \\ 73 & 31 & 0 & 0 & 0 & 86 & 70 & 100 & 0 & 0 & 14 \\ 64 & 6 & 0 & 0 & 0 & 86 & 0 & 0 & 0 & 11 & 0 \\ 15 & 0 & 0 & 0 & 0 & 14 & 0 & 0 & 0 & 0 & 0 \\ 90 & 57 & 50 & 0 & 0 & 14 & 70 & 100 & 11 & 0 & 0 \\ 2 & 5 & 25 & 0 & 0 & 0 & 80 & 0 & 0 & 0 & 0 \\ 97 & 30 & 75 & 0 & 0 & 0 & 0 & 0 & 89 & 78 & 86 \\ 95 & 27 & 25 & 0 & 60 & 0 & 0 & 0 & 0 & 22 & 0 \\ 2 & 4 & 0 & 100 & 0 & 86 & 90 & 100 & 11 & 11 & 0 \\ 3 & 0 & 0 & 0 & 0 & 0 & 0 & 0 & 0 & 0 & 0 \\ 0 & 0 & 0 & 0 & 60 & 14 & 0 & 0 & 0 & 0 & 0\end{array}$

* Results include A. bovis serotype 2 CDC W 1755.

Cluster 13 contained only strains of Arachnia propionica. At $86 \% S_{S M}$ this cluster comprised two subclusters. Subcluster a included ATCC 14157 and ATCC 29324, both serotype 1 , the 'Fleischmann' strain and three other HIK isolates. The serotype 2 reference culture and two HIK strains were recovered in subcluster b. Good differential characters for subcluster a were the fermentation of adonitol, meso-inositol and trehalose, and the production of ammonia from ornithine, serine and alanine. Of the subcluster $b$ strains, $50 \%$ were able to ferment meso-erythritol, to produce ammonia from arginine, methionine and urea, and to break down hyaluronic acid, in contrast to the $100 \%$ negative response of all subcluster a cultures.

Cluster 14 represented a group of unidentified HIK strains, which linked with cluster 13 at $79 \% S_{S M}$.

Clusters 15 and 16. All strains of Bacterionema matruchotii included in the study were recovered in cluster 15 . Similarly, cluster 16 consisted only of cultures of Rothia dentocariosa, but was divided into two subclusters at $86 \% S_{S M}$.

Clusters 17 to 22 were entirely composed of reference cultures of the genus Propionibacterium, the majority of which grouped in accordance with their species designations. With the $S_{J}$ coefficient, the only change which occurred in these clusters was the separation of $P$. lymphophilum ATCC 27520 from the two strains of $P$. jensenii in cluster 21 .

This analysis included only two duplicated reference cultures. However, a previous preliminary computation with 25 duplicated strains without identification labels established the test error as $1.6 \%$. This was calculated by $p / 2$, where $p$ is the percentage deviation from 100 (Sneath \& Johnson, 1972).

As an aid to identification, the percentage positive reactions of the major taxa are given in Table 2. Identification of members of the Actinomycetaceae can be made on many salient 
Table 3. Characters which may be of use in the differentiation of strains of A. naeslundii and $A$. viscosus (percentages of positive reactions)

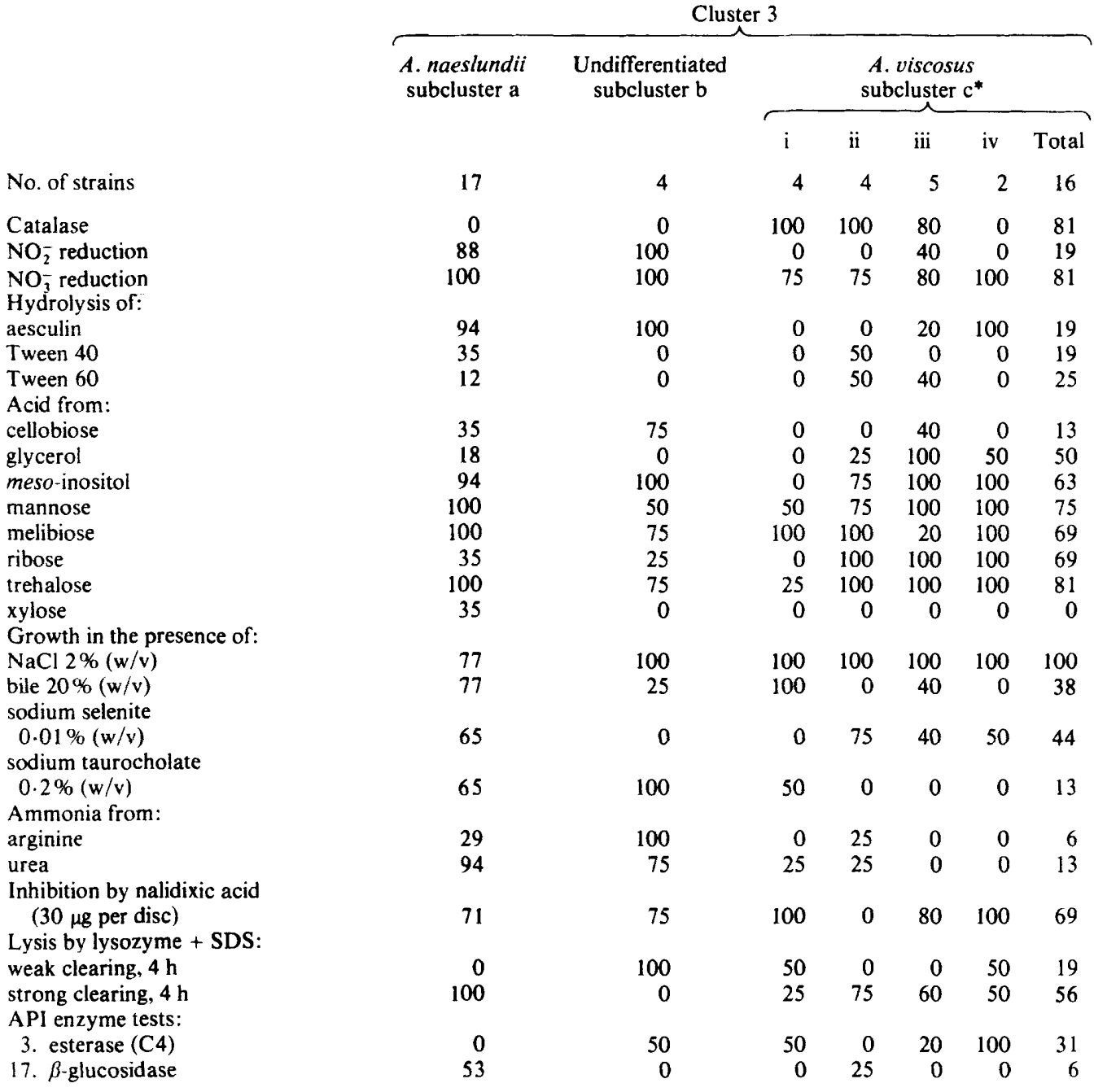

* Subgroups: i, A. viscosus serotype 1; ii, A. viscosus serotype 2; iii, 'atypical' A. viscosus strains; iv, A. naeslundii serotype 3 strains (B120, B102). The total includes results for the ungrouped strain B236.

features. Aerobic growth is characteristic only of Rothia, Bacterionema and a few $A$. naeslundii and $A$. viscosus strains. Confusion between $A$. viscosus and Rothia can occur, but separation is possible by the cytochrome oxidase test, nitrite reduction, increased $\mathrm{pH}$ in peptone-containing media, discoloration of human blood agar and production of ammonia from serine, all of which are usually strongly positive reactions of Rothia strains. On the other hand, rothiae do not ferment dextrin, melibiose and raffinose and do not produce ammonia from urea, tests which were positive for A. viscosus. Differentiation of Bacterionema from Rothia can be made by the following characters: hydrolysis of aesculin and starch; production of acid from melezitose, ribose, trehalose and $\alpha$-methyl-D-glucoside; growth in presence of $10 \%(\mathrm{w} / \mathrm{v})$ bile and $0.01 \%(\mathrm{w} / \mathrm{v})$ potassium tellurite; decarboxylation of lysine, ornithine and methionine; production of hyaluronidase, and leucine and cystine arylamidase.

Major problems have existed in the differentiation of isolates of $A$. naeslundii and $A$. viscosus. Suitable diagnostic characters are therefore presented separately in Table 3 . The 
Table 4. Characteristics of Propionibacterium strains contained in clusters 17-22 as percentages of positive reactions

\section{Reference \\ cultures associated \\ with phenon}

No. of strains

Cluster no.

Colony rough

Colony smooth

Gram-positive

Gram-variable

Cells filamentous

Cells diphtheroidal

Aerobic growth

Enhanced growth with increased $\mathrm{CO}_{2}$

Anaerobic growth (absence of

$\mathrm{CO}_{2}$ )

Cytochrome oxidase:

pale blue

deep blue

Catalase

$\mathrm{NO}_{2}^{-}$reduction

$\mathrm{NO}_{3}$ - reduction

DNAase

Indole

Hydrolysis tests:

aesculin

gelatin

starch

casein

Tween 20

Tween 40

Tween 60

Tween 80

lecithinase

lipase - egg yolk

Alkali produced in peptone-

containing media

Acid from:

arabinose

adonitol

amygdalin

cellobiose

dulcitol

dextrin

iso-erythritol

meso-erythritol

fructose

galactose

glucose

glycerol

meso-inositol

lactose

mannitol

mannose

maltose

melibiose

melezitose

raffinose

\begin{tabular}{|c|c|c|c|c|c|}
\hline 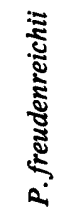 & 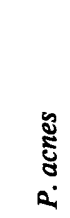 & 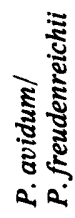 & 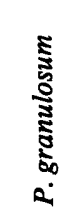 & 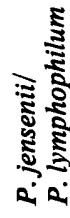 & 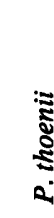 \\
\hline $\begin{array}{r}3 \\
17\end{array}$ & $\begin{array}{r}2 \\
18\end{array}$ & $\begin{array}{r}3 \\
19\end{array}$ & $\begin{array}{r}2 \\
20\end{array}$ & $\begin{array}{r}3 \\
21\end{array}$ & $\begin{array}{r}2 \\
22\end{array}$ \\
\hline $\begin{array}{r}0 \\
100\end{array}$ & $\begin{array}{r}0 \\
100\end{array}$ & $\begin{array}{r}0 \\
100\end{array}$ & $\begin{array}{r}0 \\
100\end{array}$ & $\begin{array}{r}0 \\
100\end{array}$ & $\begin{array}{r}0 \\
100\end{array}$ \\
\hline 100 & 100 & 100 & 100 & 100 & 100 \\
\hline 0 & 0 & 0 & 0 & 0 & 0 \\
\hline 0 & 0 & 0 & 0 & 0 & 0 \\
\hline 100 & 100 & 100 & 100 & 100 & 100 \\
\hline 0 & 0 & 0 & 0 & 100 & 100 \\
\hline 100 & 100 & 100 & 100 & 100 & 100 \\
\hline 0 & 100 & 67 & 100 & 0 & 0 \\
\hline 100 & 100 & 100 & 0 & 100 & 100 \\
\hline 0 & 0 & 0 & 100 & 0 & 0 \\
\hline 100 & 100 & 100 & 100 & 0 & 0 \\
\hline 67 & 0 & 100 & 0 & 33 & 0 \\
\hline 67 & 0 & 100 & 0 & 33 & 0 \\
\hline 33 & 0 & 100 & 100 & 0 & 0 \\
\hline 33 & 100 & 0 & 0 & 0 & 0 \\
\hline 33 & 0 & 33 & 0 & 33 & 100 \\
\hline 0 & 50 & 67 & 50 & 0 & 33 \\
\hline 0 & 0 & 100 & 100 & 0 & 100 \\
\hline 0 & 50 & 67 & 0 & 0 & 0 \\
\hline 0 & 0 & 0 & 0 & 0 & 0 \\
\hline 33 & 100 & 100 & 100 & 0 & 0 \\
\hline 0 & 100 & 100 & 100 & 0 & 100 \\
\hline 0 & 0 & 33 & 0 & 0 & 0 \\
\hline 0 & 0 & 33 & 100 & 0 & 0 \\
\hline 0 & 0 & 0 & 100 & 0 & 0 \\
\hline 0 & 0 & 0 & 0 & 0 & 0 \\
\hline 33 & 0 & 33 & 0 & 67 & 0 \\
\hline 67 & 0 & 67 & 0 & 67 & 100 \\
\hline 0 & 0 & 33 & 0 & 33 & 100 \\
\hline 0 & 0 & 0 & 0 & 33 & 0 \\
\hline 0 & 0 & 0 & 0 & 0 & 0 \\
\hline 0 & 0 & 100 & 0 & 33 & 100 \\
\hline 67 & 50 & 100 & 0 & 100 & 100 \\
\hline 33 & 50 & 67 & 0 & 100 & 100 \\
\hline 67 & 100 & 100 & 100 & 100 & 100 \\
\hline 100 & 50 & 100 & 100 & 67 & 100 \\
\hline 100 & 100 & 100 & 100 & 100 & 100 \\
\hline 67 & 0 & 33 & 0 & 100 & 100 \\
\hline 67 & 0 & 100 & 0 & 67 & 100 \\
\hline 67 & 0 & 0 & 0 & 67 & 100 \\
\hline 0 & 50 & 0 & 0 & 33 & 0 \\
\hline 67 & 100 & 100 & 50 & 100 & 100 \\
\hline 33 & 0 & 100 & 100 & 100 & 100 \\
\hline 0 & 0 & 0 & 50 & 33 & 100 \\
\hline 0 & 0 & 0 & 50 & 33 & 100 \\
\hline 0 & 0 & 0 & 50 & 33 & \\
\hline
\end{tabular}


Table 4 (continued)

\begin{tabular}{|c|c|c|c|c|c|c|}
\hline Cluster no. & 17 & 18 & 19 & 20 & 21 & 22 \\
\hline rhamnose & 0 & 0 & 33 & 0 & 0 & 0 \\
\hline ribose & 0 & 50 & 100 & 50 & 100 & 100 \\
\hline sorbitol & 0 & 50 & 33 & 0 & 33 & 0 \\
\hline sucrose & 0 & 0 & 100 & 100 & 67 & 100 \\
\hline trehalose & 33 & 50 & 67 & 100 & 33 & 100 \\
\hline xylose & 0 & 0 & 0 & 0 & 0 & 0 \\
\hline$\alpha$-methyl-D-glucoside & 0 & 0 & 0 & 0 & 0 & 0 \\
\hline$\alpha$-methyl-D-mannoside & 0 & 0 & 0 & 0 & 0 & 0 \\
\hline \multicolumn{7}{|l|}{ Growth in the presence of: } \\
\hline $\mathrm{NaCl} 2 \%(w / v)$ & 100 & 100 & 100 & 100 & 100 & 100 \\
\hline $4 \%(w / v)$ & 100 & 50 & 100 & 100 & 33 & 100 \\
\hline $6 \%(w / v)$ & 100 & 50 & 33 & 100 & 0 & 50 \\
\hline bile $5 \%(w / v)$ & 100 & 100 & 100 & 100 & 100 & 100 \\
\hline $10 \%(w / v)$ & 100 & 100 & 100 & 100 & 100 & 100 \\
\hline $20 \%(\mathrm{w} / \mathrm{v})$ & 67 & 100 & 100 & 100 & 100 & 100 \\
\hline sodium selenite $0.01 \%(w / v)$ & 100 & 50 & 33 & 0 & 0 & 50 \\
\hline potassium tellurite $0.01 \%(\mathrm{w} / \mathrm{v})$ & 100 & 100 & 67 & 100 & 0 & 0 \\
\hline sodium azide $0.005 \%(\mathrm{w} / \mathrm{v})$ & 100 & 100 & 100 & 100 & 100 & 100 \\
\hline crystal violet $0.005 \%(\mathrm{w} / \mathrm{v})$ & 0 & 0 & 0 & 0 & 33 & 0 \\
\hline sodium taurocholate $0.2 \%(w / v)$ & 67 & 100 & 67 & 100 & 33 & 100 \\
\hline \multicolumn{7}{|l|}{$\begin{array}{l}\text { Growth characteristics on blood } \\
\text { agar: }\end{array}$} \\
\hline human - grey/green discoloration & 0 & 0 & 0 & 0 & 0 & 0 \\
\hline human - clearing and discoloration & 67 & 0 & 100 & 100 & 0 & 100 \\
\hline sheep - grey/green discoloration & 0 & 0 & 0 & 0 & 0 & 0 \\
\hline sheep - clearing and discoloration & 67 & 50 & 100 & 100 & 0 & 100 \\
\hline horse - clearing and discoloration & 0 & 0 & 100 & 100 & 0 & 100 \\
\hline \multicolumn{7}{|l|}{ Ammonia from: } \\
\hline arginine & 33 & 100 & 0 & 0 & 33 & 0 \\
\hline lysine & 0 & 0 & 0 & 50 & 0 & 0 \\
\hline ornithine & 0 & 0 & 0 & 0 & 0 & 0 \\
\hline serine & 100 & 100 & 100 & 100 & 33 & 50 \\
\hline alanine & 67 & 0 & 0 & 0 & 0 & 0 \\
\hline methionine & 0 & 0 & 0 & 0 & 0 & 0 \\
\hline aspartic acid & 100 & 100 & 100 & 50 & 33 & 0 \\
\hline glutamic acid & 0 & 0 & 0 & 0 & 0 & 0 \\
\hline leucine & 0 & 0 & 0 & 0 & 0 & 0 \\
\hline urea & 0 & 100 & 100 & 100 & 33 & 0 \\
\hline \multicolumn{7}{|l|}{ Decarboxylation of: } \\
\hline lysine & 0 & 0 & 0 & 0 & 0 & 0 \\
\hline ornithine & 0 & 0 & 0 & 0 & 0 & 0 \\
\hline methionine & 0 & 0 & 0 & 0 & 0 & 0 \\
\hline leucine & 0 & 0 & 0 & 0 & 0 & 0 \\
\hline aspartic acid & 0 & 0 & 0 & 0 & 0 & 0 \\
\hline glutamine & 0 & 0 & 0 & 0 & 0 & 0 \\
\hline \multicolumn{7}{|l|}{ Inhibition by ( $\mu \mathrm{g}$ per disc): } \\
\hline nalidixic acid (30) & 0 & 50 & 0 & 100 & 67 & 0 \\
\hline \multicolumn{7}{|l|}{ sulphamethoxazole trimethoprim } \\
\hline$(25)$ & 33 & 100 & 33 & 100 & 100 & 100 \\
\hline amikacin (10) & 0 & 100 & 0 & 100 & 100 & 100 \\
\hline cefoxitin (30) & 33 & 100 & 100 & 100 & 100 & 100 \\
\hline oxytetracycline (30) & 100 & 100 & 0 & 100 & 100 & 100 \\
\hline Hyaluronidase & 33 & 50 & 100 & 100 & 0 & 0 \\
\hline Chondroitin sulphatase & 33 & 0 & 100 & 100 & 0 & 0 \\
\hline \multicolumn{7}{|l|}{ Lysis by lysozyme + SDS: } \\
\hline weak clearing, $4 \mathrm{~h}$ & 0 & 0 & 0 & 0 & 0 & 0 \\
\hline weak clearing, $24 \mathrm{~h}$ & 0 & 0 & 0 & 0 & 0 & 0 \\
\hline strong clearing, $4 \mathrm{~h}$ & 100 & 50 & 0 & 0 & 0 & 0 \\
\hline strong clearing, $24 \mathrm{~h}$ & 100 & 0 & 0 & 0 & 0 & 0 \\
\hline \multicolumn{7}{|l|}{$\begin{array}{l}\text { End-products of glucose } \\
\text { fermentation: }\end{array}$} \\
\hline acetic acid & 100 & 100 & 100 & 100 & 100 & 100 \\
\hline propionic acid & 100 & 100 & 100 & 50 & 100 & 100 \\
\hline
\end{tabular}




Cluster no.
butyric acid
isovaleric acid
caproic acid
pyruvic acid
lactic acid
succinic acid
API enzyme tests:
2. alkaline phosphatase
3. esterase (C4)
4. esterase lipase (C8)
5. lipase (C14)
6. leucine arylamidase
7. valine arylamidase
8. cystine arylamidase
10. chymotrypsin
11. acid phosphatase
12. phosphoamidase
13. $\alpha$-galactosidase
14. $\beta$-galactosidase
15. $\beta$-glucuronidase
16. $\alpha$-glucosidase
17. $\beta$-glucosidase
18. $N$-acetyl- $\beta$-glucosaminidase
19. $\alpha$-mannosidase
20. $\alpha$-fucosidase

Table 4 (continued)

$\begin{array}{rrrrrr}17 & 18 & 19 & 20 & 21 & 22 \\ 0 & 0 & 0 & 0 & 0 & 0 \\ 0 & 100 & 67 & 100 & 67 & 100 \\ 0 & 0 & 0 & 0 & 0 & 0 \\ 0 & 0 & 0 & 0 & 0 & 0 \\ 0 & 0 & 0 & 100 & 0 & 0 \\ 100 & 50 & 0 & 100 & 33 & 0 \\ & & & & & \\ 0 & 50 & 0 & 0 & 0 & 0 \\ 67 & 0 & 100 & 100 & 100 & 100 \\ 67 & 50 & 67 & 100 & 100 & 0 \\ 0 & 0 & 0 & 0 & 0 & 0 \\ 100 & 0 & 100 & 100 & 100 & 100 \\ 0 & 0 & 0 & 0 & 0 & 0 \\ 100 & 0 & 0 & 0 & 67 & 100 \\ 0 & 0 & 0 & 0 & 0 & 0 \\ 0 & 100 & 100 & 0 & 67 & 100 \\ 33 & 100 & 100 & 0 & 67 & 100 \\ 67 & 0 & 0 & 100 & 100 & 0 \\ 33 & 100 & 100 & 0 & 0 & 100 \\ 0 & 100 & 0 & 0 & 0 & 0 \\ 100 & 50 & 100 & 100 & 100 & 100 \\ 67 & 0 & 100 & 100 & 100 & 100 \\ 0 & 100 & 100 & 0 & 0 & 100 \\ 0 & 100 & 100 & 0 & 0 & 100 \\ 0 & 0 & 0 & 0 & 0 & 0\end{array}$

most useful are: nitrite reduction; aesculin hydrolysis; production of acid from cellobiose, glycerol and ribose; and production of ammonia from urea. All of these could easily be used for routine identification.

The $A$. israelii phenon exhibits many diagnostic features, particularly the sugar fermentation reactions, lack of growth in presence of bile salts and the production of ammonia from arginine. Tests useful for differentiation of the subclusters are: hydrolysis of gelatin by strains in subcluster a; lack of tolerance to $2 \%(\mathrm{w} / \mathrm{v}) \mathrm{NaCl}$, sensitivity to lysozyme after $4 \mathrm{~h}$ and tolerance to potassium tellurite by strains in subcluster b; failure to reduce nitrate by most strains in subcluster c; a mostly diphtheroidal shape and failure to ferment trehalose by subcluster $d$ isolates.

Clusters 7, 9, 10,11 and 12 are readily distinguished from all other phena. They share many features, but can be separated on the basis of DNAase, starch, casein and Tween hydrolysis, especially clusters 10,11 and 12 . Within these five clusters, the fermentation of glycerol by cluster 7 strains is uncommon, as is the fermentation of ribose by strains in clusters 9 and 10. The production of ammonia from arginine is useful for identification of cluster 9 strains and susceptibility to lysozyme after $4 \mathrm{~h}$ is characteristic of cluster 10 .

Cluster 13, which contains only strains of Arachnia propionica, is characterized by: the pattern of sugar fermentation reactions; production of ammonia from serine and alanine; non-susceptibility to lysozyme after $4 \mathrm{~h}$; production of propionic acid as a major end-product of glucose fermentation; production of esterase and esterase lipase.

Characters useful for the identification of the six clusters of Propionibacteria are given in Table 4.

\section{DISCUSSION}

As has been noted in many previous studies (Boone \& Pine, 1968; de Weese et al., 1968; Holmberg \& Nord, 1975; Pine, 1970), A. israelii is a well-defined taxon which links at rather 
low similarity levels with other species of the genus Actinomyces. It is therefore possible that these organisms deserve recognition as a separate genus in the family Actinomycetaceae. Further investigations with the serotypes and with strains from the subclusters delimited in cluster 1 may show these subgroups to be equivalent to species in a newly erected genus.

Unfortunately most of the other Actinomyces species are not so clearly defined. It has previously been suggested that $A$. naeslundii and $A$. viscosus should be combined (Holmberg \& Hallander, 1973; Slack \& Gerencser, 1975), a view also supported to a certain extent by several serological studies (Bowden et al., 1976; Collins et al., 1973; Holmberg \& Forsum, 1973; Gerencser \& Slack, 1967). In the numerical taxonomic study of Holmberg \& Nord (1975) five representatives of these species grouped together in one subcluster at $92.5 \% S_{S M}$, the other subcluster consisting of $\boldsymbol{A}$. odontolyticus. In the present study these species once again grouped together (cluster 3 ), but formed a discrete set of subclusters which were defined by all coefficients employed. One large subcluster contained only $A$. naeslundii strains. The subcluster of $A$. viscosus cultures was divided into four groups. Three represented the animal serotype 1 strains (i), the human serotype 2 strains (ii) and the 'atypical' human $A$. viscosus isolates (iii). These groupings are in good agreement with the recent work of Fillery et al. (1978) who used biochemical and cell wall data to separate strains of $A$. viscosus into those of human (serotype 2) and animal (serotype 1) origin and defined a group of 'typical' $A$. naeslundii strains. Using the $S_{1}$ nuclease hybridization method with strains from the clusters defined by Fillery et al. (1978), Coykendall \& Munzenmaier (1979) delineated a group of 'atypical' $A$. naeslundii strains. One of these 'atypical' strains, LHMC B120, was included in our study. It did not fall in the main $A$. naeslundii subclusters and was recovered in subgroup c (iv). Both groups of workers also described an 'atypical' $A$. viscosus strain (W1053= ATCC $27044=$ WVU 474) which in our study clustered with other 'atypical' strains in the small subgroup iii.

There were a relatively large number of ungrouped strains at the peripheries of phena 3 and 4. Many fell into one of these clusters in the $D_{P}$ analysis, but several single isolates remained outside the groups. Most of these strains were recent isolates and were included in this study because they showed characteristics which differed from those presently used to define $A$. viscosus or $A$. naeslundii.

The species $A$. naeslundii and $A$. viscosus are closely related and possibly should be combined. However, an increasing number of differential characters between these two species are being found, as illustrated here (Table 3) and in the recent work of Fillery et al. (1978) and Coykendall \& Munzenmaier (1979). Actinomyces naeslundii appears to be a more coherent taxon than $A$. viscosus, with the exceptions of serotype 3 strains B 120 and B102 which require further investigation. Actinomyces viscosus serotypes 1 and 2 are phenotypically different (Table 3 ) and the genetic evidence (Coykendall \& Munzenmaier, 1979) also suggests that they are sufficiently distinct to merit separation, perhaps at the subspecies level. The DNA of the animal strain A. viscosus ATCC 15987 serotype 1 contains $60.9 \mathrm{~mol} \%$ GC whereas that of the human strain ATCC 19246 serotype 2 contains $67.4 \%$ (Coykendall et al., 1974). Therefore, at present $A$. naeslundii and $A$. viscosus should remain separate species within which delineation of further smaller subgroups may be possible.

The Actinomyces odontolyticus cluster was linked to the $A$. naeslundii/A. viscosus cluster when the pattern coefficient was employed, but with the other coefficients it was joined to the phena containing $A$. bovis, $C$. pyogenes and Erysipelothrix rhusiopathiae. These last three phena were grouped together by all statistical patterns used. The close relationship of $A$. bovis and $C$. pyogenes is particularly interesting. To date, all numerical studies have indicated that C. pyogenes and the supposedly closely related species $C$. haemolyticum (Cummins \& Harris, 1956; Harrington, 1966) are distinct from other members of the genus Corynebacterium, but lack any clear association with other bacterial groups. However, our results do not indicate a very close relationship between $C$. pyogenes and C. haemolyticum. Slack \& Gerencser (1975) considered the possibility of a relationship between $C$. pyogenes, $A$. bovis and $A$. 
odontolyticus, and our results show that there is probably a close taxonomic association between $A$. bovis and $C$. pyogenes.

Actinomyces bovis, the type species of the genus, was well-separated from the other species of Actinomyces. It also possesses a different cell wall composition (Schleifer \& Kandler, 1972) having a peptidoglycan type found in many lactobacilli and bifidobacteria. Other species of Actinomyces are closely related by cell wall type (Slack \& Gerencser, 1975). One reference culture of Bifidobacterium bifidum ATCC 17930 (CDC W753) formerly designated Actinomyces parabifidus, and one HIK strain previously identified as a Bifidobacterium sp. were associated with $A$. bovis at $82 \% S_{S M}$. The other two representatives of the genus Bifidobacterium were found in cluster 5 .

Erysipelothrix has been associated with the lactic acid bacteria (Sneath \& Cowan, 1958; Jones, 1978) and is at present classified as a genus of uncertain affiliation in Bergey's Manual (Seeliger, 1974). However, the present study gave little indication of any relationship with $L$. casei or L. plantarum. All coefficients used grouped together the Erysipelothrix cluster with those of $A$. bovis and $C$. pyogenes. The association may have been based on the large number of negative characters shared by these three species; the clusters joined at $48 \%$ with the $S_{J}$ coefficient.

The three other genera of the family Actinomycetaceae - Rothia, Bacterionema and Arachnia - were grouped together at rather low similarity values (Fig. 1). At present all are single species genera, but other species may exist (Bowden \& Hardie, 1978). It has been suggested that serotype $2 \mathrm{Ar}$. propionica strains are sufficiently different from serotype 1 to warrant status as a distinct species (Gerencser \& Slack, 1967; Slack \& Gerencser, 1975). Our results agree with these proposals, serotypes 1 and 2 being well separated. This is in contrast to the numerical study of Holmberg \& Nord (1975) where representatives of serotypes 1 and 2 were linked at $95 \% S_{S M}$. However, these workers included a large number of morphological characters which could have increased the similarity values.

It has been proposed that Ar. propionica be moved to the genus Propionibacterium (Pine, 1970), but Johnson \& Cummins (1972) found low DNA homologies between various species of Propionibacterium and Arachnia strains. Our results indicate that, at present, the genus Arachnia should remain in the Actinomycetaceae.

Another genus of uncertain taxonomic affiliation is Bacterionema. Strains of this genus formed a distinct cluster having little relationship with other genera of the Actinomycetaceae or with any other species studied. The inclusion of Bacterionema within the currently defined family Actinomycetaceae is doubtful because of the occurrence of mycolic acids, DL-diaminopimelic acid and arabinose in the cell wall. Although our results do not solve this problem, previous work has shown a close relationship with the genus Corynebacterium (Minnikin et al., 1978).

In conclusion, our results indicate that the genus Actinomyces contains at least three taxa which could merit recognition at the generic level. These are: $A$. israelii; $A$. naeslundii, $A$. viscosus and $A$. odontolyticus; and $A$. bovis. There is an association between $A$. bovis and $C$. pyogenes, which needs further genetic and chemical investigation. The relationship between Bifidobacterium bifidum and $A$. bovis also requires further study. The genus Arachnia, which should probably stay within the family Actinomycetaceae, could be separated into two species equivalent to serotypes 1 and 2 . Of the other genera, Rothia may also contain more than one species, and Bacterionema may possibly be reclassified in the genus Corynebacterium. However, because of the lack of sufficient chemotaxonomic and genetic data it is too soon to propose redefinition of the family Actinomycetaceae.

The study was in part supported by grant Scha 304/1 from the Deutsche Forschungsgemeinschaft. We are grateful to Miss R. Büchel and Mrs D. Bohsem for technical assistance and to Mrs S. Glanschneider for photographic services. Some of the materials used for the fermentation tests were kindly provided by Becton Dickinson, Heidelberg. 


\section{REFERENCES}

Boone, C. J. \& Pine, L. (1968). Rapid method for characterization of actinomycetes by cell wall composition. Applied Microbiology 16, 279-284.

Bowden, G. \& HARDIE, J. (1978). Oral pleiomorphic (coryneform) Gram-positive rods. In Coryneform Bacteria, pp. 235-263. Edited by I. J. Bousfield \& A. G. Callely. London \& New York: Academic Press.

Bowden, G., Hardie, J. M. \& Fillery, E. D. (1976). Antigens from Actinomyces species and their value in identification. Journal of Dental Research, Special Issue A 55, 193-204.

Collins, P. A., Gerencser, M. A. \& Slack, J. M. (1973). Enumeration and identification of Actinomycetaceae in human dental calculus using the fluorescent antibody technique. Archives of Oral Biology 18, 145-153.

COWAN, S. T. \& STEEL, K. J. (1975). Manual for the Identification of Medical Bacteria. Cambridge: Cambridge University Press.

Coykendall, A. L. \& Munzenmaier, A. J. (1979). Deoxyribonucleic acid hybridization among strains of Actinomyces viscosus and Actinomyces naeslundii. International Journal of Systematic Bacteriology 29, 234-240.

Coykendall, A. L., Lee, T. W. \& Brown, A. T. (1974). Isolation and base content of deoxyribonucleic acid (DNA) from Actinomyces viscosus strains. Abstracts, IADR 74, 73.

Cummins, C. S. \& Harris, H. (1956). The chemical composition of the cell wall in some Gram-positive bacteria and its possible value as a taxonomic character. Journal of General Microbiology 14, $583-600$.

Deibel, R. H. \& Evans, J. B. (1960). Modified benzidine test for the detection of cytochromecontaining respiratory systems in microorganisms. Journal of Bacteriology 79, 356-360.

Fillery, E. D., Bowden, G. H. \& Hardie, J. M. (1978). A comparison of strains designated Actinomyces viscosus and Actinomyces naeslundii. Caries Research 12, 299-312.

FORTNER, J. (1928). Ein einfaches Plattenverfahren zur Züchtung strenger Anaerobier. Zentralblatt für Bakteriologie, Parasitenkunde, Infektionskrankheiten und Hygiene (Abteilung I, Originale) 108, 155-158.

ForTNER, J. (1929). Zur Technik der anaeroben Züchtung. Zentralblatt für Bakteriologie, Parasitenkunde, Infektionskrankheiten und Hygiene (Abteilung I, Originale) 110, 233-237.

GerenCSER, M. A. \& SLACK, J. M. (1967). Isolation and characterization of Actinomyces propionicus. Journal of Bacteriology 94, 109-115.

HARRINGTON, B. J. (1966). A numerical taxonomical study of some corynebacteria and related organisms. Journal of General Microbiology 45, 31-40.

HEINRICH, S. \& KORTH, H. (1967). Zur Nährbodenfrage in der Routinediagnostik der Aktinomykose: Ersatz unsicherer biologischer Substrate durch ein standardisiertes Medium. In Krankheiten durch Aktinomyzeten und Verwandte Erreger, pp. 1620. Edited by H.-J. Heite. Berlin: Springer Verlag.

Holdeman, L. V. \& Moore, W. E. C. (1972).
Anaerobe Laboratory Manual. Blacksburg, Virginia: Virginia Polytechnic Institute and State University.

HOLMBERG, K. \& FORSUM, U. (1973). Identification of Actinomyces, Arachnia, Bacterionema, Rothia and Propionibacteria species by defined immunofluorescence. Applied Microbiology 25, 834-843.

HolmberG, K. \& Hallander, H. O. (1973). Numerical taxonomy and laboratory identification of Bacterionema matruchotii, Rothia dentocariosa, Actinomyces naeslundii, Actinomyces viscosus and some related bacteria. Journal of General Microbiology 76, 43-63.

HolmberG, K. \& NoRD, C. E. (1975). Numerical taxonomy and laboratory identification of Actinomyces and Arachnia and some related bacteria. Journal of General Microbiology 91, 17-44.

Johnson, J. L. \& Cummins, C. S. (1972). Cell wall composition and DNA similarities among the anaerobic coryneforms, classical propionibacteria and strains of Arachnia propionica. Journal of Bacteriology 109, 1047-1066.

JoNEs, D. (1978). An evaluation of the contributions of numerical taxonomic studies to the classification of coryneform bacteria. In Coryneform Bacteria, pp. 13-46. Edited by I. J. Bousfield \& A. G. Callely. London \& New York: Academic Press.

Melville, T. H. (1965). A study of the overall similarity of certain actinomycetes mainly of oral origin. Journal of General Microbiology 40, 309315.

Minnikin, D. E., Goodfellow, M. \& Collins, M. D. (1978). Lipid composition in the classification and identification of coryneform and related taxa. In Coryneform Bacteria, pp. 85-160. Edited by I. J. Bousfield \& A. G. Callely. London \& New York: Academic Press.

Moore, W. E. C. \& Holdeman, L. V. (1974). In Bergey's Manual of Determinative Bacteriology, 8th edn, p. 633. Edited by R. E. Buchanan \& N. E. Gibbons. Baltimore: Williams \& Wilkins.

Mordarska, H., Cebrat, S., Blach, B. \& GoodFELLOW, M. (1978). Differentiation of nocardioform actinomycetes by lysozyme sensitivity. Journal of General Microbiology 109, 381-384.

PiNE, L. (1970). Classification and phylogenetic relationships of microaerophilic actinomycetes. International Journal of Systematic Bacteriology 20, 445-474.

SchaAl, K. P. \& Pulverer, G. (1973). Fluoreszenzserologische Differenzierung von fakultativ anaeroben Aktinomyzeten. Zentralblatt für Bakteriologie, Parasitenkunde, Infektionskrankheiten und Hygiene (Abteilung I, Originale A) 225, 424-430.

SchaAl, K. P. \& Pulverer, G. (1981). The genera Actinomyces, Agromyces, Arachnia, Bacterionema, and Rothia. In The Prokaryotes: $A$ Handbook of Habitats, Isolation and Identification of Bacteria. Edited by M. P. Starr, H. Stolp, H. G. Trüper, A. Balows \& H. G. Schlegel. New York: Springer Verlag (in the Press).

SchaAl, K. P. \& Schofield, G. M. (1981a). Current ideas on the taxonomic status of the Actino- 
mycetaceae. Zentralblatt für Bakteriologie, Parasitenkunde, Infektionskrankheiten und Hygiene, Suppl. 11, 67-68.

SchaAl, K. P. \& Schofield, G. M. (1981b). Taxonomy of Actinomycetaceae. Revue de l'Institut Pasteur de Lyon 14, 27-39.

Schaal, K. P., Schofield, G. M. \& Pulverer, G. (1980). Taxonomy and clinical significance of Actinomycetaceae and Propionibacteriaceae. Infection 8, Suppl. 2, 122-130.

Schleifer, K. H. \& Kandler, O. (1972). Peptidoglycan types of bacterial cell walls and their taxonomic implication. Bacteriological Reviews 36, 407-477.

SChofield, G. M. \& SchaAl, K. P. (1979). Application of the Minitek differentiation system in the classification and identification of Actinomycetaceae. FEMS Microbiology Letters 5, 311-313.

Schofield, G. M. \& SchaAl, K. P. (1980a). Carbohydrate fermentation patterns of facultatively anaerobic actinomycetes using micromethods. FEMS Microbiology Letters 8, 67-69.

Schofield, G. M. \& SchaAl, K. P. $(1980 b)$. Rapid micromethods for detecting deamination and decarboxylation of amino acids, indole production, and reduction of nitrate and nitrite by facultatively anaerobic actinomycetes. Zentralblatt für Bakteriologie, Parasitenkunde, Infektionskrankheiten und Hygiene (Abteilung I, Originale A) 247, 383-391.

SEELIGER, H. P. R. (1974). In Bergey's Manual of Determinative Bacteriology, 8 th edn, p. 597. Edited by R. E. Buchanan \& N. E. Gibbons. Baltimore: Williams \& Wilkins.

SLACK, J. M. (1974). In Bergey's Manual of Determinative Bacteriology, 8th edn, p. 659. Edited by R. E. Buchanan \& N. E. Gibbons. Baltimore: Williams \& Wilkins.

Slack, J. M. \& Gerencser, M. A. (1975). Actinomyces, Filamentous Bacteria. Biology and Pathogenicity. Minneapolis, Minnesota: Burgess Publishing Co.

SNEATH, P. H. A. (1957). The application of computers to taxonomy. Journal of General Microbiology 17, 201-226.

SNEATH, P. H. A. (1968). Vigour and pattern in taxonomy. Journal of General Microbiology 54, $1-11$.

SNeath, P. H. A. \& Cowan, S. T. (1958). An electrotaxonomic survey of bacteria. Journal of General Microbiology 19, 551-565.

SNEATH, P. H. A. \& Johnson, R. (1972). The influence on numerical taxonomic similarities of errors in microbiological tests. Journal of General Microbiology 72, 377-392.

SOKAL, R. R. \& Michener, C. D. (1958). A statistical method for evaluating systematic relationships. Kansas University Science Bulletin 38, 1409-1438.

DE Weese, M. S., Gerencser, M. A. \& Slack, J. M. (1968). Quantitative analysis of Actinomyces cell walls. Applied Microbiology 16, 1713-1718.

Wishart, D. (1978). Clustan User Manual. Edinburgh: Program Library Unit, Edinburgh University. 